NBER WORKING PAPER SERIES

\title{
THE ROLE AND FUNCTIONING OF PUBLIC-INTEREST LEGAL ORGANIZATIONS IN THE ENFORCEMENT OF THE EMPLOYMENT LAWS
}

\author{
Christine Jolls \\ Working Paper 10708 \\ http://www.nber.org/papers/w10708 \\ NATIONAL BUREAU OF ECONOMIC RESEARCH \\ 1050 Massachusetts Avenue \\ Cambridge, MA 02138 \\ August 2004
}

The views expressed herein are those of the author(s) and not necessarily those of the National Bureau of Economic Research.

(C2004 by Christine Jolls. All rights reserved. Short sections of text, not to exceed two paragraphs, may be quoted without explicit permission provided that full credit, including $\mathbb{C}$ notice, is given to the source. 
The Role and Functioning of Public-Interest Legal Organizations in the Enforcement of the Employment Laws

Christine Jolls

NBER Working Paper No. 10708

August 2004

JEL No. J00, J78, K31, K49

\section{ABSTRACT}

Many laws create important rights for today's employees, but the availability of legal representation for employees seeking to enforce those rights is uncertain. The goal of the present paper, part of the Emerging Labor Market Institutions for the 21st Century Project at the National Bureau of Economic Research, is to examine some of the distinctive public-interest legal organizations that exist to help to enforce the employment laws. The chapter focuses on two broad categories of such organizations: "national issue organizations," which are organizations that focus on one or more broad-based issues and are funded predominantly by private donations; and legal services organizations, which serve exclusively low-income individuals and are funded primarily by the government.

Christine Jolls

Harvard Law School

Cambridge, MA 02138

and NBER

cjolls@nber.org 


\title{
The Role and Functioning of Public-Interest Legal Organizations in the Enforcement of the Employment Laws
}

\author{
Christine Jolls*
}

\section{Introduction}

Today's American legal system affords a significant array of protections to employees. Although most workers in this country do not enjoy a general right to be dismissed only for cause-a right characteristic of many European countries (Issacharoff 1996:1806-07) and now of one American state, Montana (Mont. Code Ann. secs. 39-2-901 to 39-2-915)-they benefit from a host of specific prohibitions on arbitrary or inappropriate behavior by employers. Examples include prohibitions on discriminatory behavior (on the basis of race, sex, religion, national origin, age, or disability) and on behavior that interferes with other personal rights of employees. Employers are also under certain affirmative obligations to employees, including the obligation to provide a safe workplace and the obligation (indirectly, through experience-rated insurance premiums) to fund unemployment benefits for employees who are out of work. ${ }^{1}$

There is, however, a critical and oft-emphasized distinction between the law "on the books" and the law "in action," as the Legal Realist movement famously taught long ago (Pound 1910). What ultimately matters for many, if not most, purposes is how the law actually operates, not what protections it ostensibly provides. The law "in action" includes not only how courts

\footnotetext{
* Professor of Law, Harvard Law School, and Research Associate, NBER. This research was prepared for the NBER/MacArthur Project on Emerging Labor Market Institutions for the 21st Century. The research was prepared in 1999-2001 and reflects facts and sources as they existed at that time. Sam Bagenstos and Margo Schlanger offered extremely helpful comments on and reactions to this work. Thanks go as well to Amanda Rocque for outstanding research assistance, and to participants in the May 1999 and August 2000 Emerging Labor Market Institutions conferences for helpful suggestions. Special thanks to Kip Viscusi and David Weil, the commentators on this chapter at the August 2000 session, for their help. Finally, financial support from the John M. Olin Center for Law, Economics and Business at Harvard Law School is gratefully acknowledged.
}

For an overview of legal obligations on employers, see Willborn, Schwab and Burton (1998). 
apply the law as written (the original emphasis of the Realists) but also how well the law is enforced by the institutions and parties affected by it (Llewellyn 1930:435 n.3).

The distinction between law "on the books" and law "in action" is clearly important in the employment law context, where employees are ordinarily not in a strong position to enforce their rights. Indeed, Roscoe Pound (1910:35), the father of "on the books"-“in action" distinction, wrote almost a century ago that "our copious labor legislation for the most part fails of effect because of defective administration." The significant decline in union membership in recent decades, from its high in the middle of the twentieth century, can only have exacerbated the problem.

The goal of the present chapter is to examine some of the distinctive public-interest legal organizations that exist to help to enforce the employment laws. The chapter focuses on two broad categories of such organizations: "national issue organizations" (for instance, the NAACP Legal Defense and Education Fund), which are defined here as organizations that focus on one or more broad-based issues and are funded predominantly by private donations; and legal services organizations, which serve exclusively low-income individuals and are funded primarily by the government. The focus, as just indicated, is on "enforcement" (or "implementation") of existing laws, not "enactment" of new laws, to use the dichotomy drawn by David Weil (2001:[draft at 3]) in his contribution to this volume.

Many different mechanisms exist for "enforcing" the employment laws. The mechanisms include, most obviously, providing conventional legal representation to employees whose rights may have been violated, but they also include providing information to workers about what rights the law gives them, facilitating the enforcement of these rights through means other than filing lawsuits, and providing research and support assistance to attorneys providing 
direct representation to clients. There are a number of examples of entities providing these latter sorts of services; the Workplace Project of Long Island, for instance, offers informational courses for workers (Trubek 1998:806) and facilitates enforcement of employment laws through means other than litigation (Gordon 1995:430-37), and the Migrant Legal Action Program offers research and support assistance to attorneys who provide direct representation to migrant workers. $^{2}$ Many legal web sites also offer employment law information to workers. ${ }^{3}$ For reasons of scope, however, this chapter focuses on the more conventional activity of direct legal representation of employee interests.

It is interesting to note in this connection that Charles Tilly and other theorists of social movement apparently have not viewed such litigation or representation activity as a central component of social movement, since it is not necessarily "outsider" behavior. I agree, by contrast, with Paul Burstein (1991:1203-05, 1222), who, after making this observation about Tilly and other theorists, argues that litigation is an important element of social movement. This importance justifies the emphasis I give it here.

Section 1 below lays the groundwork for the examination of the role of public-interest legal organizations in representing employees by describing why the usual mechanism for

2 See wysiwyg://152/http://buscapique.com/latinuse/buscafile/wash/mlap.htm (visited 7/11/00). Additional examples of such entities, providing support to attorneys involved in direct legal representation, include Legal Services for the Elderly, of New York City, and the National Association of Protection and Advocacy Systems. See http://www.aoa.dhhs.gov/aoa/dir/118.html (visited 7/7/00) (description of Legal Services for the Elderly; this organization does not provide services directly to clients, but it offers support and advice to other attorneys representing the elderly); http://www.protectionandadvocacy.com/napas.htm (visited 7/14/00) (description of the National Association of Protection and Advocacy Systems, which provides various forms of technical assistance and support to state-level "protection and advocacy" organizations for the disabled). 3 See, for example, http://www.nwjustice.org/law_center/employment.html (visited 9/21/99) (web site of the Northwest Justice Project, which offers, among other things, a download-able document on "Your Rights and Responsibilities as an Employee"). 
protecting legal rights-retention of a private lawyer by the aggrieved party-is of limited effectiveness in the employment context. Section 2 overviews some of the key features of national issue organizations and legal services centers (the organizations on which this chapter focuses). Section 3 provides institutional detail on how the two types of organizations are funded. Finally, section 4 develops the chapter's primary analytic point, which is the way in which funding sources exert a significant and often problematic influence on the sort of employment law litigation in which an organization engages-a species of the general point about the influence of funding sources on public-interest legal organizations (Komesar and Weisbrod 1978:96-97). As discussed below, national issue organizations, funded largely through donations, do primarily high-level, high-impact work in areas with a significant public profile, such as discrimination; by contrast, legal services centers, supported by the government, work primarily at low levels and in areas, such as unemployment benefits, that lack the public profile of areas such as discrimination. This distinction between the two types of organizations is not absolute (there are some exceptions), and also there are other types of public-interest legal organizations that do some work in the employment arena, but still the overall pattern of activity seems to be what the distinction between national issue organizations and legal services centers suggests.

As a result of this pattern of activity, neither national issue or organizations nor legal services centers succeeds very well in meeting the full set of needs of employees for enforcement of the employment laws. For both types of organizations, a very important component of the organizational objective function is attracting or maintaining funding from either large private donors (such as foundations) or the government, and this focus on receiving such forms of funding detracts from the organizations' ability to serve the full range of their constituencies' 
needs (see also Weil 2001:[draft at 17-18]). My conclusion here complements Weil's suggestion that reliance on either unions or small individual donors with a personal connection to the issues in question (see also Hersch 2001:[draft at 1, 28]) provides "better alignment between the objectives of the groups and those of the workers they intend to assist" (Weil 2001:[draft at 1819]).

A final terminological point is important here. Lawyers commonly distinguish between "employment law" and "labor law," where the former is the body of (largely substantive) rules protecting workers regardless of union status, while the latter is the body of (often procedural) rules governing the formation and conduct of unions and their relationships with employers. This chapter follows that terminological distinction; thus its focus on organizations involved in enforcing "the employment laws" means a focus on organizations that work on employment law, not labor law, issues.

\section{The limited efficacy of private legal representation in the employment law context}

In most of the economy, the primary institution that operates to protect parties' legal rights is the private bar; an aggrieved party retains (and pays for) a lawyer who works to vindicate the client's rights. Perhaps not surprisingly, this approach seems to work less well in the employment context than in many other contexts. This is so for several reasons.

First, individual employees will quite often lack the funds to hire a lawyer on an hourly basis, the usual arrangement for large commercial clients. In this respect the problem is parallel to the one that arises in the personal injury context, where individual victims often cannot afford to hire lawyers on an hourly basis while defendant-corporations can. 
In the personal injury context the solution is representation of victims on a contingent-fee basis, where the lawyer is compensated by receipt of a share of any winnings garnered by the accident victim. But employees generally do not have as great an opportunity to hire lawyers on a contingent fee basis as do victims of personal injuries. The reason is that employees' damages are ordinarily far lower than those of personal injury victims. It is true that some employment law claims sound in tort (like personal injury claims) and thus can produce verdicts for millions of dollars; in Wilson v. Monarch, 939 F.2d 1138 (5th Cir. 1991), for instance, an employee netted a $\$ 3.1$ million verdict on a tort claim for emotional distress. However, a large number of employment claims-most prominently, discrimination claims brought under federal law-do not fall into this potential-seven-figure-verdict category. Until 1991, employees in such cases were limited to "equitable" relief (reinstatement together with limited amounts of lost wages) (see, for example, Selmi 1998:1427-28), and even now monetary relief beyond what was available under the old regime is capped at amounts ranging from $\$ 50,000$ to $\$ 300,000$ depending on the size of the offending employer (see 42 U.S.C. sec. 1981a(b)(3)). (State claims, however, are not subject to these caps.) Also consistent with the idea that limited damages pose a barrier to private representation in the employment area is the fact that age discrimination plaintiffs are generally viewed as having the easiest time finding legal representation, and their damages are generally higher than those of other employment discrimination plaintiffs (Rutherglen 1995:505-09).

A further dimension of the problem of relying exclusively on privately-hired attorneys to bring employment law claims is that the potential damages of the employee will frequently be highly correlated with the employee's earnings. Thus employees who earn low to modest wages-and thus are particularly unable to hire hourly-fee attorneys-will also tend to be particularly unattractive to contingent-fee practitioners. 
A third reason for the limited efficacy of privately retained counsel in the employment law context is that, while some employment laws do provide for the recovery of attorney fees, that right is limited in important respects and often does not provide private attorneys with sufficient compensation to ensure that taking an employment case is worthwhile. To begin, it is primarily antidiscrimination laws, as distinguished from other employment laws, that provide for the recovery of attorney fees at all; other sorts of laws may not contain such provisions. ${ }^{4}$ Moreover, even those laws that do authorize the recovery of attorney fees authorize recovery only if the employee is the prevailing party in the case. ${ }^{5}$ In addition, if a party prevails but only to a limited extent, attorney fees are accordingly limited. ${ }^{6}$ A final, and critical, point is that even if fees are recoverable, there is no upward adjustment to account for the risk that the employee's attorney would end up not prevailing. ${ }^{7}$ The lack of an upward adjustment means that on an expected basis attorney fee awards under the employment law statutes that permit them at all are systematically undercompensatory relative to the attorney's performance of work on a regular hourly-fee basis.

4 Examples of laws that authorize the recovery of attorney fees under certain circumstances include Title VII of the Civil Rights Act of 1964, see 42 U.S.C. sec. 2000e-5(k), and the Americans with Disabilities Act, see 42 U.S.C. sec. 12205.

5 See, for example, 42 U.S.C. sec. 2000e-5(k) (Title VII attorney fee provision); 42 U.S.C. sec. 12205 (disability discrimination attorney fee provision).

6 See Farrar v. Hobby, 506 U.S. 103, 114-16 (1992). Farrar involved an action under 42 U.S.C. sec. 1983 outside of the employment law context. However, the Supreme Court has made clear that its interpretations of fee-shifting provisions apply to such provisions in general, including those in employment statutes. See, for example, Buckhannon Board and Care Home, Inc. v. West Virginia Department of Health and Human Resources, 121 S.Ct. 1835, 1839 n.4 (2001). Numerous courts of appeals have applied Farrar to the fee-shifting provisions under employment statutes. See, for example, Pino v. Locascio, 101 F.3d 235, 237-39 (2d Cir. 1996); Brandau v. State of Kansas, 168 F.3d 1179, 1181-83 (10th Cir. 1999).

7 See City of Burlington v. Dague, 505 U.S. 557, 562-67 (1992). City of Burlington involved a statute permitting attorney fees in environmental cases, but the Court made clear that its reasoning applied to other fee-shifting provisions-including those in employment statutes-as well. See id. at 561-62. 
For all of these reasons, the "ordinary" approach of privately-retained legal counsel is a very incomplete strategy for the enforcement of the employment laws. As Lewis Maltby (1998:56) has written, “The economic hurdles facing an employee who seeks justice in court are staggering." An intriguing question, not addressed here because it would go too far afield from the central topic of this chapter, is why "prepaid legal services" (programs under which individuals make advance payments, in the nature of insurance premiums, for future legal services) have had relatively little effect in achieving legal representation for employees.

The point here is of course not that representation by privately-retained counsel in employment law matters is never available. One institution of particular importance in providing such representation is the "private public interest law firm." Firms in this category are private law firms that are supported by ordinary legal fees but that may represent certain clients for reduced fees based on the client's level of need. As Louise Trubek (1996:436) writes, "Social justice law firms serve diverse social classes by using sliding-scale fee schedules based on income ...." In the employment law context, the paying clients may be unions and the subsidized clients may be individual employees. In addition, class action suits brought by private counsel may play a role in vindicating employees' rights in some contexts.

Nonetheless, notwithstanding the existence of a role for private counsel on the employee side, it remains the case that alternative institutional arrangements, and in particular the publicinterest legal organizations discussed in this chapter, have an important role to play in the enforcement of the employment laws. In addition to the points about retention of private counsel described above, there is the overarching fact that, as described by Weil (2001:[draft at 9-10]) in this volume and also by Burton Weisbrod (1978:20-21), enforcing many aspects of employment 
(or other laws) involves a significant public good component-a fact that suggests the need to rely at least in part on various sorts of public entities for enforcement.

An obvious question to ask in light of the comment just made concerns the potential role of the government in the enforcement of the employment laws. Often, of course, the government has a role to play when the private market fails to provide a particular good or service. However, for a variety of reasons that have been explored in the existing literature, the government is limited in its ability to provide direct legal representation for employees, both as a matter of theory and as an empirical matter (Handler 1978b:259-68; Selmi 1998:1427-38, 1447-49). Thus, there remains an important role for the public-interest legal organizations discussed in this chapter to play.

Along with the government, unions are an institution that obviously can help to overcome public-good-type problems. Consistent with this suggestion, union counsel can and do play a role in enforcing the employment laws in addition to their work in labor law arenas. Examples of such union counsel include the AFL-CIO General Counsel's Office and the legal counsel of the American Federation of State, County and Municipal Employees (AFSCME), each of which has been involved in a number of important employment law cases. ${ }^{8}$ Professor Catherine Fisk goes so far as to describe union initiatives in the employment law area as "major efforts to

8 See, for example, Brief of the American Federation of Labor and Congress of Industrial Organizations as Amicus Curiae in Support of Petitioners, Christensen v. Harris County, No. 981167, United States Supreme Court, 1999 WL 1114682 (amicus brief in employment law case involving the Fair Labor Standards Act); Brief of the American Federation of Labor and Congress of Industrial Organizations as Amicus Curiae in Support of Petitioners, Sutton v. United Air Lines, No. 97-1943, United States Supreme Court, 1999 WL 86514 (amicus brief in employment law case involving the Americans with Disabilities Act); http://www.afscme.org/about/ofcman08.htm (visited 7/7/00) (“AFSCME's lawyers initiate and assist in legal actions taken at both the federal and state levels which address . . civil rights issues that affect AFSCME members and affiliates."); http://www.afscme.org/about/womenrts.htm (visited 7/7/00) (describing AFSCME's litigation efforts to achieve pay equity for women). 
enforce employment law in nonunion workplaces" (Fisk 2001). The role of such union counsel thus complements the role of the public-interest legal organizations emphasized here.

\section{National issue organizations and legal services centers-in general}

The present section describes two leading types of public-interest legal organizations involved in the employment law area. The first is national issue organizations; as noted above, these are national entities that focus on a particular set of issues or topics (related at least in part to employment law) and are funded largely or exclusively by sources other than the government. The second is legal services centers; these provide legal representation to low-income individuals at government expense. The present section presents introductory information on the two types of organizations, and the following section discusses in more detail how the organizations are funded. The goal of these two sections together is to paint a descriptive picture of the two types of organizations, similar in spirit to-but with different emphases than-the portrait offered of public interest legal organizations in general (not with specific reference to the employment law area) offered more than twenty years ago by Joel Handler, Betsy Ginsberg and Arthur Snow (1978).

This section relies heavily on Internet presence to describe and identify organizations. In this respect it differs from earlier work (for instance, O’Connor and Epstein 1989; Sturm 1993b), which relied significantly on mass-mailed surveys to gather information. The advantage of relying on the Internet is the likely greater accuracy, on average, of information as compared to what is reported by a particular individual in response to a survey. The obvious limit of the present methodology, of course, is that entities with an Internet presence will receive disproportionate coverage. 


\section{a. National issue organizations}

Table 1 provides a list of entities that qualify as national issue organizations according to the above definition. Note that an organization need not be exclusively devoted to employment law issues to meet the definition; indeed, most of the entities listed divide their time between employment and other issues, including housing, education, and consumer rights. An organization also need not be exclusively devoted to litigation, as opposed to other forms of public advocacy, to meet the definition. As long as litigation-meaning representation of clients in lawsuits, negotiating settlements, filing amicus briefs, and so forth-is an important component of the entity's activity, the entity qualifies as a national issue organization. ${ }^{9}$ As already noted, funding information is presented in section 3 below.

9 One example of a national entity that works on employment law issues but does not engage in any litigation is the Pension Rights Center, which is active in public advocacy in the media and in testifying before Congress but provides referrals for individuals seeking legal representation. See http://www.aoa.dhhs.gov/aoa/dir/210.html (visited 7/11/00) (listing attorney referral, but not direct representation, as one of PRC's services); http://labor.senate.gov/hearings/septhear/092199wt/09219jmj/leahy921/brown/iwry/krueger/cha mbers/gebhard/ferguson/body_ferguson.htm (visited 7/13/00) (Senate testimony); wysiwyg://375/http://www.commondreams.org/pressreleases/july99/072799d.htm (visited 7/11/00) (example of press release). Another example is the National Employee Rights Institute, which provides information and referrals to workers but does not engage in significant litigation itself. See http://www.nerinet.org/ (visited 7/12/00) (describing NERI's activities). 
Table 1: National issue organizations (devoted at least in part to employment law issues)

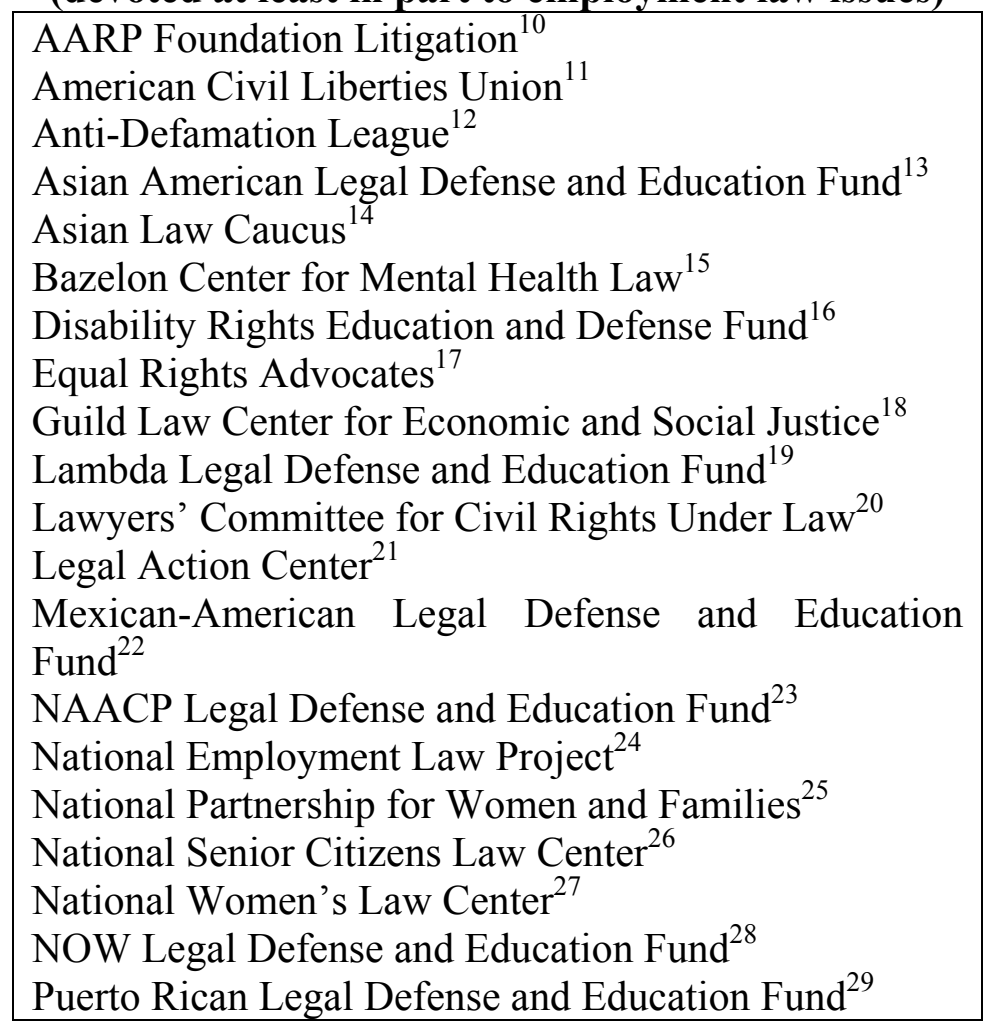

10 See http://www.aarp.org/litigation/ (visited 8/31/01) (mission statement describing employment law as well as other areas of litigation).

11 See, for example, http://www.aclu.org/issues/immigrant/workrights.html (visited 7/6/00) (employment litigation activities of the American Civil Liberties Union's Immigrant Rights Project); http://www.aclu.org/issues/gay/aboutgl.html (visited 7/6/00) (describing employment discrimination suit, Shahar v. Bowers, brought by the American Civil Liberties Union against the state of Georgia).

12 See http://www.adl.org/frames/front_civil_rights.html (visited 7/13/00) (Civil Rights Report, ADL in the Courts: Litigation Docket 1999, at 35-36, 40-43) (describing employment law litigation).

13 See 1998 Annual Report, Asian American Legal Defense and Education Fund, at 5-7 (describing employment law litigation activities).

14 See http://www.peggybrowningfund.org/alc.html (visited 7/10/00) (describing the Asian Law Caucus's Employment/Labor Project).

15 See 1998-99 Annual Report, Bazelon Center for Mental Health Law, at 5 (describing recent employment discrimination suit brought by the Bazelon Center); http://www.bazelon.org/who.html (general description of the Bazelon Center's activities).

16 See, for example, http://www.dredf.org/sandiego.html (visited 9/1/99) (describing employment discrimination suit brought by the Disability Rights Education and Defense Fund and others against the City of San Diego, CA); 
http://www.dredf.org/christensen.html (visited 9/1/99) (describing employment discrimination suit brought by the Disability Rights Education and Defense Fund and others against the Los Angeles Police Department).

17 See http://www.equalrights.org/legal/amicusbr.htm (visited 7/10/00) (describing current litigation activity, a substantial portion of which is in the employment law area).

18 See http://sugarlaw.org/projects/plantclosings/plantclosingsproject.htm (visited 7/11/00) (describing Plant Closings Project and its litigation activity under the Worker Adjustment and Retraining Notification (WARN) Act).

19 See 1998 Annual Report, Lambda Legal Defense and Education Fund, at 8-9, 11 (describing employment law litigation activities).

20 See, for example, http://www.lawyerscomm.org/projects/employ.html (visited 7/6/00) (describing the Lawyers' Committee's Employment Discrimination Project);

http://www.lawyerscomm.org/accompli.html (visited 7/6/00) (describing legal victories in employment cases including Claiborne Hardware Co. v. NAACP and Women in City Government United v. New York).

21 See Lopez (1998:446) (describing focus on employment discrimination).

22 See 1998-99 Annual Report, Mexican-American Legal Defense and Education Fund, at 6-7 (describing employment law litigation activities).

23 See 1998 Annual Report, NAACP Legal Defense and Education Fund, at 10-11 (describing employment law litigation activities).

24 See, for example, http://www.nelp.org/about.html (visited 7/6/00) (general description of the organization); http://www.nelp.org/immigrant.htm (visited 7/6/00) (description of Immigrant Worker Project and its litigation activities);

http://www.nelp.org/contingent.htm (visited 7/6/00) (describing Contingent Worker Project and accompanying litigation activities).

25 See 1997-98 Annual Report, National Partnership for Women and Families, at 5, 7 (describing employment law litigation activities).

26 See http://www.nsclc.org/about.html (visited 7/7/00) (listing pension rights and age and disability discrimination as focus areas, and stating that "NSCLC has a long tradition of national advocacy through impact litigation"); http://www.nsclc.org/consumers.html (visited 7/7/00) (describing how to contact the organization's attorneys for potential legal representation).

27 See http://www.afl.org/mem.nwlc.html (visited 7/11/00) (general description of organization's role in litigating women's rights in areas including employment); Brief of the Women's Legal Defense Fund et al. in Support of Petitioners, Walters v. Metropolitan Educ. Enterprises, Inc., Nos, 95-259, 95-779, United States Supreme Court, 1996 WL 284703 (amicus brief in employment discrimination case, signed by the National Women's Law Center among others).

28 See 1998 Annual Report, NOW Legal Defense and Education Fund, at 2-3 (describing employment law litigation activities).

29 See http://guthrie.hunter.cuny.edu/centro/archives/aids/prldef.html (visited 7/10/00) (noting that the Puerto Rican Legal Defense and Education Fund has brought lawsuits across the country in a range of areas including equal employment rights, and listing project areas including Employment Rights). 
The organizations in Table 1 vary significantly in the proportion of their time devoted to employment law issues, both as a fraction of the organization's overall activity and in absolute terms. In terms of the fraction of an organization's overall activity, the National Employment Law Project is exclusively devoted to employment law issues, while a relatively small proportion of the overall activities of the Bazelon Center appears to involve such issues. (Note that, as discussed more fully in section 4 below, the National Employment Law Project was previously a government-funded "support center" for local legal services centers.) Similarly, in terms of the absolute level of employment law work, the activities of the NAACP Legal Defense and Education Fund, with close to two dozen staff attorneys, ${ }^{30}$ are surely substantially greater in magnitude than those of the Equal Rights Advocates, with four staff attorneys. ${ }^{31}$ If, however, employment law involvement is relatively rare or quite sporadic, then I do not include the organization in Table $1 .{ }^{32}$

Omitted from Table 1 are organizations that do not have staffs of their own lawyers but rather provide coordinating services to their attorney membership, which engages in employment law litigation. These organizations are not providing direct client representation as I conceive of

30 See 1998 Annual Report, NAACP Legal Defense and Education Fund, at 2.

31 See http://www.equalrights.org/about/director.htm (visited 7/12/00).

32 For instance, Table 1 does not include People for the American Way; PFAW has been involved in employment law litigation on a few occasions, but such litigation does not appear to be a regular staple of its activity. See http://www.pfaw.org/courts/priorcases.shtml (visited 7/7/00) (describing PFAW's involvement in the Supreme Court litigation in Oncale v. Sundowner and Piscataway School District v. Taxman); http://www.pfaw.org/courts/docket.shtml (visited 7/7/00) (current docket of cases in which PFAW is involved, none of which are employment cases). Similarly, the National Center for Lesbian Rights focuses on a range of discrimination and civil rights issues but does not appear to work on employment law matters and thus is not listed in Table 1. See http://www.nclrights.org/cases.html (visited 7/10/00) (current docket of cases in which NCLR is involved, none of which are employment cases). The same is true of Trial Lawyers for Public Justice. See http://www.tlpj.org/tlpjf/caseup.htm (visited 7/11/00) (summary of current cases, none of which are employment cases). 
it. The most prominent example of such an organization in the employment area is the National Employment Lawyers Association, which coordinates amicus-brief-writing activities by its members but does not employ the attorneys who write the briefs. ${ }^{33}$

As discussed in section 4 below, in addition to the organizations listed in Table 1 there are entities that look similar to these organizations but seem to predominantly (although not necessarily exclusively) operate on a more regional or local level; examples (all listed in Table 3 below) include the Asian Pacific American Legal Center of Southern California, the Center for Law in the Public Interest, the Employment Law Center of the Legal Aid Society of San Francisco, Gay \& Lesbian Advocates \& Defenders, the Northwest Women's Law Center, Public Advocates, Inc., and the Public Justice Center.

\section{b. Legal services centers}

A second leading type of public-interest legal organization involved in the enforcement of the employment laws is legal services centers. These centers arose in the 1960s as part of the federal government's War on Poverty (Bellow 1980:337-38). Since 1974 the centers have been administered through the Legal Services Corporation, an arm of the federal government that makes grants of funds to local centers around the country. ${ }^{34}$

Legal services centers provide legal representation free of charge across a range of areas to low-income clients who cannot afford ordinary private lawyers. ${ }^{35}$ The eligibility cutoff established at the federal level is at $125 \%$ of the federal poverty guidelines, and local centers

33 See http://www.nela.org/ (visited 7/12/00) (general description of the organization); The Employee Advocate, Spring 2000, at 6, 10 (describing amicus brief activity of NELA attorneys).

34 See http://www.lsc.gov/welcome/wel_who.htm (visited 7/14/00) (general description of the Legal Services Corporation).

35 See, for example, http://firms.findlaw.com/LASP/ (visited 9/21/99) (Legal Services Program for Pasadena and San Gabriel-Pomona Valley) (describing organization's activities). 
may, if they choose, limit their services to persons even closer to the poverty line (Spar 1996:2). As examples of the income cutoff levels, Alaska Legal Services sets the cutoff for a family of three at $\$ 21,700$, while Gulfcoast Legal Services of Florida sets it at $\$ 17,063 .{ }^{36}$ As a result of the cutoffs, legal services centers cover only a distinct subset of the population of individuals who may be unable to retain a private lawyer for representation on an employment law matter. As Justice Denise Johnson of the Vermont Supreme Court has noted, "It is not just the poor who cannot afford justice in today's society. Courts across the country have experienced an explosion in pro se litigation" (where the client is not represented by an attorney), "and many people representing themselves are of modest income levels and would not be eligible for publicly funded legal services" (Johnson 1998:480-81).

Legal services centers perform limited work in the employment law area (Gordon 1995:422); indeed, many potential clients may be entirely unaware of their ability to get help with employment law matters from legal services entities. The Legal Services Corporation compiles aggregate statistics on the types of cases handled by legal services centers. Nationwide, income maintenance claims, which include claims for unemployment benefits as well as other types of public benefits, ${ }^{37}$ comprise about a sixth of the overall caseload of legal services centers. ${ }^{38}$ Other employment cases are a few percent of the overall caseload. ${ }^{39}$

36 See http://www.ptialaska.net/ aklegal/ (visited 9/21/99) (Alaska Legal Services Corporation); http://www.gulfcoastlegal.org/guidelines.htm (visited 9/21/99) (Gulfcoast Legal Services).

37 See http://www.gulfcoastlegal.org/priorities.htm (visited 9/21/99) (Gulfcoast Legal Services) (listing unemployment benefits in income maintenance category, not employment category); http://209.212.129.85/priorities.html (visited 9/22/99) (Three Rivers Legal Services, Inc.) (also listing unemployment benefits in income maintenance category).

38 See, for example, 1997 Annual Report, Legal Services Corporation, at 4 (income maintenance cases were $14.0 \%$ of cases closed in 1997).

39 See id. (employment cases were $2.4 \%$ of cases closed in 1997). 
A few of the local legal services centers provide detailed quantitative breakdowns of their activities by subject matter. Atlanta Legal Aid, for example, reports an annual caseload for 1997 of 11,552 total cases, of which 241 involved unemployment benefits, 74 involved discrimination claims, and 185 involved other employment claims. ${ }^{40}$ The Maryland Legal Aid Bureau reports an annual caseload for 1998 of 33,048 total cases, of which 2,256 (7\%) involved income maintenance and 743 (2\%) involved employment matters other than unemployment benefits claims. ${ }^{41}$ The Legal Aid Society of Nebraska reports a 1997 annual caseload of 4,762 cases, of which 286 involved income maintenance and 19 involved employment matters other than unemployment benefits claims. ${ }^{42}$ Many other centers, however, do not even have an "employment" category apart from the income maintenance category. ${ }^{43}$

\section{Funding of national issue organizations and legal services centers}

The previous section described national issue organizations and legal services centers involved in employment law representation. This section examines the manner in which these organizations are funded.

\section{a. National issue organizations}

As already noted, and as discussed more fully below, legal services centers get a substantial amount of funding from the government. National issue organizations, by contrast,

40 See http://www.law.emory.edu/PI/ALAS/97cases.html (visited 9/21/99).

41 See http://www.mdlab.org/Statistics.html (visited 9/21/99).

42 See http://www.las.omaha.org/1997Rep.htm (visited 9/21/99).

43 See, for example, http://www.mlan.net/lacm/Whattemplace.html (visited 9/22/99) (listing of types of cases handled by Legal Aid of Central Michigan); http:/homepage.rconnect.com/smrlswi/index/htm (visited 9/22/99) (listing of types of cases handled by Southern Minnesota Regional Legal Services). 
typically get little or no government funding. Neither the NAACP Legal Defense and Education Fund nor the Lambda Legal Defense and Education Fund, for example, appears to have gotten any government support in 1998, according to their annual reports for that year; the NOW Legal Defense and Education Fund received a government grant for $\$ 394,682$, approximately $10 \%$ of its total revenue. ${ }^{44}$ Some national issue organizations, such as the American Civil Liberties Union, categorically refuse to accept any government funding on principle $;^{45}$ presumably these organizations fear that such funding would comprise their ability to bring aggressive, broadbased challenges, particularly when those challenges involve the government in any way. The history of legal services funding, discussed in section 4 below, provides a good deal of support for these concerns about the consequences of accepting government funding.

The primary sources of funding for national issue organizations are generally individual contributions and foundation grants; other sources include attorneys' fees and donation of private attorneys' time. ${ }^{46}$ Often contributions by the government or by corporations are grouped with foundation grants in the reporting of financial information, ${ }^{47}$ so the category of foundation

44 See 1998 Annual Report, NAACP Legal Defense and Education Fund, at 25-27 (listing institutional donors at length, and describing how to make individual contributions, but making no mention of government funding); 1998 Annual Report, Lambda Legal Defense and Education Fund, at 31 (dividing donors into "foundations" and "individuals," while making no mention of government funding); 1998 Annual Report, NOW Legal Defense and Education Fund, at 17 (listing government grant of $\$ 394,682$ ).

45 See http://www.aclu.org/library/pbp1.html (visited 7/6/00) ("The ACLU does not receive any government funding").

46 See, for example, 1998 Annual Report, NAACP Legal Defense and Education Fund, at 24 (listing attorney fees and costs as the source of $\$ 1,116,878$ in revenue, just under $10 \%$ of the total intake); 1998 Annual Report, Lambda Legal Defense and Education Fund, at 31 (listing donated legal services as the source of $\$ 961,962$ in revenue, approximately $20 \%$ of the total intake).

47 See, for example, 1996 Annual Report, NOW Legal Defense and Education Fund, at 17 (grouping contributions from foundations and government in a single category); 1998 Annual Report, NOW Legal Defense and Education Fund, at 17 (grouping contributions from foundations and corporations in a single category); 1998 Annual Report, NAACP Legal Defense 
support as discussed here includes those additional sources of funding. As noted above, however, government funding appears limited, and the same is generally true of corporate contributions, to the extent one can tell from the information that is publicly reported. ${ }^{48}$

Across the two major categories of funding for national issue organizations-individual contributions and contributions from foundations-the organizations vary considerably in the proportion of funding that comes from each source. For example, according to figures from annual reports, in 1998 the Mexican American Legal Defense and Education Fund got 33\% of its funding from individual contributors, and $47 \%$ from foundations, while the Lambda Legal Defense and Education Fund got $69 \%$ of its funding from individual contributors and only $8 \%$ from foundations. ${ }^{49}$ (It should be noted that such differences conceivably could result from variations in how organizations categorize different contributions. Unfortunately, none of the national issue organizations' annual reports provide a great deal of detail about how they compute the various figures. On the other hand, the fact that the organizations' financial reports are audited presumably suggests at least some commonality of practice across them. Still, this caveat should be borne in mind in interpreting the figures given here.)

An interesting normative dimension of the differences in sources of funds is that some types of national issue organizations may have greater access to foundation funds than others. A striking feature of data I compiled for four national issue organizations-the NOW Legal Defense and Education Fund, the Lambda Legal Defense and Education Fund, the Mexican American

and Education Fund, at 25-26 (listing "institutional donors," which include both foundations and corporations).

${ }^{48}$ For instance, the NOW Legal Defense and Education Fund currently groups contributions from foundations and corporations in a single category, but until 1996 it separated them out. In 1996 corporate contributions were $\$ 61,350$, compared to $\$ 1,281,298$ from foundations and government. See 1996 Annual Report, NOW Legal Defense and Education Fund, at 17.

49 See 1998-99 Annual Report, Mexican-American Legal Defense and Education Fund, at 24; 1998 Annual Report, Lambda Legal Defense and Education Fund, at 31. 
Legal Defense and Education Fund, and the National Partnership for Women and Families-over a several-year period is that, as already suggested above, the Lambda Legal Defense and Education Fund gets far less of its funding from foundations than any of the other national issue organizations just mentioned. Foundations may be more likely to contribute to more "conventional" civil rights organizations than to organizations such as Lambda's. (Lambda's central focus is facilitating and protecting civil rights for lesbians, gay men, and bisexual individuals.) The funding pattern described here is consistent with Felix Lopez's observation about the difficulty of attracting foundation support for representation in employment law matters of ex-offenders, people in recovery, and people with AIDS (Lopez 1998:453).

\section{b. Legal services organizations}

The fundamental contrast between national issue organizations and legal services centers in terms of their funding is that while the former get little to no government funding, the latter get a substantial (albeit decreasing) fraction of their funding from government sources. The following analysis presents more detailed information on the funding of legal services centers and how it differs from the funding of national issue organizations.

Table 2 shows both the absolute dollar amounts and the percentage of funding for legal services centers from a range of sources for the years 1980 to 1998 . The second column of the table gives the amount of funding from the Legal Services Corporation; ${ }^{50}$ the third column gives the amount of funding from other federal government sources (for instance, social services

\footnotetext{
50 Actually this figure is approximate, since the dollar amount in the second column of Table 2 is the congressional appropriation to the Legal Services Corporation; most, but not all, of this amount ultimately flows to legal services centers in the form of grants.
} 
grants) ${ }^{51}$ the fourth column gives the amount of funding from state and local government sources; the fifth column gives the amount of funding from IOLTA, or Interest on Lawyers Trust Accounts; ${ }^{52}$ and the sixth column gives the amount of funding from other sources. The nature of these "other sources," to the extent it can be discerned from publicly available information, is discussed later in this section.

The percentage figures in Table 2 make clear that the percentage of funding for legal services centers that comes from a government source of one type or another is very large-just under $75 \%$ in 1998 , and $98 \%$ in 1980 . The composition of the government support has changed somewhat over time, however; the role of state and local governments has grown, while the role of the federal government has shrunk (from $97 \%$ of total funds in 1980 to $58 \%$ of total funds in 1998).

51 See, for example, http://www.lsnj.org/glance.htm (visited 9/22/99) (Legal Services of New Jersey) (listing federal funding from a Social Services Block Grant, Department of Human Services and Community Affairs, as well as from the Legal Services Corporation).

52 "Under these programs, certain client funds held by an attorney in connection with his practice of law are deposited in bank accounts. The interest income generated by the funds is paid to foundations that finance legal services for low-income individuals." Phillips v. Washington Legal Foundation, 524 U.S. 156, 160 (1998). 
Table 2: Funding for Legal Services Centers 1980-1998: Dollar and Percentage Figures

\begin{tabular}{|c|c|c|c|c|c|c|}
\hline Year & $\begin{array}{c}\text { Legal } \\
\text { Services } \\
\text { Corporation }\end{array}$ & Other federal & $\begin{array}{l}\text { State and } \\
\text { local }\end{array}$ & $\begin{array}{c}\text { Interest on } \\
\text { Lawyers } \\
\text { Trust } \\
\text { Accounts } \\
\text { (IOLTA) }\end{array}$ & Other & Total \\
\hline 1980 & $\begin{array}{c}\$ 300,000,000 \\
(88.85 \%)\end{array}$ & $\begin{array}{c}\$ 27,167,000 \\
(8.05 \%)\end{array}$ & $\begin{array}{c}\$ 3,557,000 \\
(1.05 \%)\end{array}$ & $\begin{array}{c}\$ 0 \\
(0.00 \%)\end{array}$ & $\begin{array}{c}\$ 6,938,000 \\
(2.05 \%)\end{array}$ & $\begin{array}{c}\$ 337,662,000 \\
(100 \%)\end{array}$ \\
\hline 1981 & $\begin{array}{c}\$ 321,300,000 \\
(86.97 \%)\end{array}$ & $\begin{array}{c}\$ 26,478,927 \\
(7.17 \%) \\
\end{array}$ & $\begin{array}{c}\$ 6,258,655 \\
(1.69 \%)\end{array}$ & $\begin{array}{c}\$ 0 \\
(0.00 \%)\end{array}$ & $\begin{array}{c}\$ 15,405,921 \\
(4.17 \%)\end{array}$ & $\begin{array}{c}\$ 369,443,503 \\
(100 \%)\end{array}$ \\
\hline 1982 & $\begin{array}{c}\$ 241,000,000 \\
(82.82 \%)\end{array}$ & $\begin{array}{c}\$ 27,500,000 \\
(9.45 \%) \\
\end{array}$ & $\begin{array}{c}\$ 6,500,000 \\
(2.23 \%)\end{array}$ & $\begin{array}{c}\$ 0 \\
(0.00 \%)\end{array}$ & $\begin{array}{c}\$ 16,000,000 \\
(5.50 \%)\end{array}$ & $\begin{array}{c}\$ 291,000,000 \\
(100 \%)\end{array}$ \\
\hline 1983 & $\begin{array}{c}\$ 241,000,000 \\
(82.26 \%)\end{array}$ & $\begin{array}{c}\$ 25,490,293 \\
(8.70 \%)\end{array}$ & $\begin{array}{c}\$ 9,522,332 \\
(3.25 \%)\end{array}$ & $\begin{array}{c}\$ 1,500,000 \\
(0.51 \%)\end{array}$ & $\begin{array}{c}\$ 15,443,426 \\
(5.27 \%)\end{array}$ & $\begin{array}{c}\$ 292,956,051 \\
(100 \%)\end{array}$ \\
\hline 1984 & $\begin{array}{c}\$ 275,000,000 \\
(81.19 \%)\end{array}$ & $\begin{array}{c}\$ 23,166,872 \\
(6.84 \%) \\
\end{array}$ & $\begin{array}{c}\$ 16,082,836 \\
(4.75 \%)\end{array}$ & $\begin{array}{c}\$ 1,273,842 \\
(0.38 \%)\end{array}$ & $\begin{array}{c}\$ 23,168,566 \\
(6.84 \%)\end{array}$ & $\begin{array}{c}\$ 338,692,116 \\
(100 \%)\end{array}$ \\
\hline 1985 & $\begin{array}{c}\$ 305,000,000 \\
(78.92 \%)\end{array}$ & $\begin{array}{c}\$ 24,718,960 \\
(6.40 \%)\end{array}$ & $\begin{array}{c}\$ 20,067,745 \\
(5.19 \%)\end{array}$ & $\begin{array}{c}\$ 2,656,146 \\
(0.69 \%)\end{array}$ & $\begin{array}{c}\$ 34,007,507 \\
(8.80 \%)\end{array}$ & $\begin{array}{c}\$ 386,450,358 \\
(100 \%)\end{array}$ \\
\hline 1986 & $\begin{array}{c}\$ 292,363,000 \\
(76.26 \%)\end{array}$ & $\begin{array}{c}\$ 25,399,966 \\
(6.63 \%) \\
\end{array}$ & $\begin{array}{c}\$ 23,730,987 \\
(6.19 \%)\end{array}$ & $\begin{array}{c}\$ 15,029,328 \\
(3.92 \%)\end{array}$ & $\begin{array}{c}\$ 26,834,413 \\
(7.00 \%)\end{array}$ & $\begin{array}{c}\$ 383,357,694 \\
(100 \%)\end{array}$ \\
\hline 1987 & $\begin{array}{c}\$ 305,500,000 \\
(71.63 \%)\end{array}$ & $\begin{array}{c}\$ 25,412,407 \\
(5.96 \%)\end{array}$ & $\begin{array}{c}\$ 30,913,128 \\
(7.25 \%)\end{array}$ & $\begin{array}{c}\$ 28,664,710 \\
(6.72 \%)\end{array}$ & $\begin{array}{c}\$ 36,026,378 \\
(8.45 \%)\end{array}$ & $\begin{array}{c}\$ 426,516,623 \\
(100 \%)\end{array}$ \\
\hline 1988 & $\begin{array}{c}\$ 305,500,000 \\
(70.28 \%)\end{array}$ & $\begin{array}{c}\$ 27,678,482 \\
(6.37 \%) \\
\end{array}$ & $\begin{array}{c}\$ 33,755,106 \\
(7.76 \%)\end{array}$ & $\begin{array}{c}\$ 29,951,205 \\
(6.89 \%)\end{array}$ & $\begin{array}{c}\$ 37,834,710 \\
(8.70 \%)\end{array}$ & $\begin{array}{c}\$ 434,719,503 \\
(100 \%)\end{array}$ \\
\hline 1989 & $\begin{array}{c}\$ 308,555,000 \\
(67.42 \%)\end{array}$ & $\begin{array}{c}\$ 28,132,139 \\
(6.15 \%)\end{array}$ & $\begin{array}{c}\$ 42,968,230 \\
(9.39 \%)\end{array}$ & $\begin{array}{c}\$ 35,994,959 \\
(7.87 \%)\end{array}$ & $\begin{array}{c}\$ 42,007,908 \\
(9.18 \%)\end{array}$ & $\begin{array}{c}\$ 457,658,236 \\
(100 \%)\end{array}$ \\
\hline 1990 & $\begin{array}{c}\$ 361,525,000 \\
(66.29 \%)\end{array}$ & $\begin{array}{c}\$ 28,473,066 \\
(5.22 \%)\end{array}$ & $\begin{array}{c}\$ 50,180,646 \\
(9.20 \%)\end{array}$ & $\begin{array}{c}\$ 55,005,222 \\
(10.09 \%)\end{array}$ & $\begin{array}{c}\$ 50,201,397 \\
(9.20 \%)\end{array}$ & $\begin{array}{c}\$ 545,385,331 \\
(100 \%)\end{array}$ \\
\hline 1991 & $\begin{array}{c}\$ 328,182,000 \\
(62.09 \%)\end{array}$ & $\begin{array}{c}\$ 29,512,709 \\
(5.58 \%) \\
\end{array}$ & $\begin{array}{c}\$ 52,023,260 \\
(9.84 \%)\end{array}$ & $\begin{array}{c}\$ 73,918,224 \\
(13.98 \%)\end{array}$ & $\begin{array}{c}\$ 44,936,714 \\
(8.50 \%)\end{array}$ & $\begin{array}{c}\$ 528,572,907 \\
(100 \%)\end{array}$ \\
\hline 1992 & $\begin{array}{c}\$ 350,000,000 \\
(59.46 \%)\end{array}$ & $\begin{array}{c}\$ 31,434,331 \\
(5.34 \%)\end{array}$ & $\begin{array}{c}\$ 58,737,676 \\
(9.98 \%)\end{array}$ & $\begin{array}{c}\$ 87,948,080 \\
(14.94 \%)\end{array}$ & $\begin{array}{c}\$ 60,517,386 \\
(10.28 \%)\end{array}$ & $\begin{array}{c}\$ 588,637,473 \\
(100 \%)\end{array}$ \\
\hline 1993 & $\begin{array}{c}\$ 357,000,000 \\
(59.22 \%)\end{array}$ & $\begin{array}{c}\$ 32,182,415 \\
(5.34 \%) \\
\end{array}$ & $\begin{array}{c}\$ 70,041,391 \\
(11.62 \%)\end{array}$ & $\begin{array}{c}\$ 75,879,344 \\
(12.59 \%)\end{array}$ & $\begin{array}{c}\$ 67,737,581 \\
(11.24 \%)\end{array}$ & $\begin{array}{c}\$ 602,840,731 \\
(100 \%)\end{array}$ \\
\hline 1994 & $\begin{array}{c}\$ 400,000,000 \\
(62.22 \%)\end{array}$ & $\begin{array}{c}\$ 34,605,425 \\
(5.38 \%)\end{array}$ & $\begin{array}{c}\$ 75,139,727 \\
(11.69 \%)\end{array}$ & $\begin{array}{c}\$ 64,882,679 \\
(10.09 \%)\end{array}$ & $\begin{array}{c}\$ 68,216,677 \\
(10.61 \%)\end{array}$ & $\begin{array}{c}\$ 642,844,508 \\
(100 \%)\end{array}$ \\
\hline 1995 & $\begin{array}{c}\$ 400,000,000 \\
(61.21 \%)\end{array}$ & $\begin{array}{c}\$ 40,000,658 \\
(6.12 \%) \\
\end{array}$ & $\begin{array}{c}\$ 75,497,133 \\
(11.55 \%)\end{array}$ & $\begin{array}{c}\$ 60,194,149 \\
(9.21 \%)\end{array}$ & $\begin{array}{c}\$ 77,821,214 \\
(11.91 \%)\end{array}$ & $\begin{array}{c}\$ 653,513,154 \\
(100 \%)\end{array}$ \\
\hline 1996 & $\begin{array}{c}\$ 278,000,000 \\
(57.08 \%)\end{array}$ & $\begin{array}{c}\$ 28,740,312 \\
(5.90 \%) \\
\end{array}$ & $\begin{array}{c}\$ 68,191,385 \\
(14.00 \%)\end{array}$ & $\begin{array}{c}\$ 53,312,540 \\
(10.95 \%)\end{array}$ & $\begin{array}{c}\$ 58,799,129 \\
(12.07 \%)\end{array}$ & $\begin{array}{c}\$ 487,043,366 \\
(100 \%)\end{array}$ \\
\hline 1997 & $\begin{array}{c}\$ 283,000,000 \\
(55.30 \%)\end{array}$ & $\begin{array}{c}\$ 27,814,679 \\
(5.44 \%) \\
\end{array}$ & $\begin{array}{c}\$ 79,884,074 \\
(15.61 \%)\end{array}$ & $\begin{array}{c}\$ 57,452,515 \\
(11.23 \%)\end{array}$ & $\begin{array}{c}\$ 63,609,910 \\
(12.43 \%)\end{array}$ & $\begin{array}{c}\$ 511,761,178 \\
(100 \%)\end{array}$ \\
\hline 1998 & $\begin{array}{c}\$ 283,000,000 \\
(51.85 \%)\end{array}$ & $\begin{array}{c}\$ 35,996,269 \\
(6.60 \%)\end{array}$ & $\begin{array}{c}\$ 87,720,710 \\
(16.07 \%)\end{array}$ & $\begin{array}{c}\$ 63,457,108 \\
(11.63 \%)\end{array}$ & $\begin{array}{c}\$ 75,594,473 \\
(13.85 \%)\end{array}$ & $\begin{array}{c}\$ 545,768,560 \\
(100 \%)\end{array}$ \\
\hline
\end{tabular}

Source: Legal Services Corporation web site, http://www.lsc.gov/sfb99app.html and http://www.lsc.gov/sfb99nlf.html (both visited 9/12/99). 
In terms of nongovernmental funding, the Legal Services Corporation data reported in Table 2 distinguishes between IOLTA funds and funds from other private sources. In fact, IOLTA funds may bear important similarities to government funds in terms of the pressures and restrictions (detailed more fully in section 4 below) that accompany the funding. Entities that receive Legal Services Corporation funds are forbidden, for example, to bring class action lawsuits or to engage in "legislative advocacy" (lobbying activity) (Udell 1998a:338); some state laws impose similar restrictions on the use of IOLTA funds (Udell 1998b:908 n.42). Also of interest for present purposes, at least one state, Washington, prohibits the use of IOLTA funds for bringing employment discrimination suits (Udell 1998b:908 n.42). (It should also be noted that the legal status of IOLTA funds remains up in the air after a 1998 Supreme Court decision involving a federal constitutional challenge to the collection of such funds (Resnick and Bazelon 1998:299).)

The remaining funding category for legal services centers reflected in the Legal Services Corporation data is funding from "other" sources. ${ }^{53}$ The 1997 Annual Report of the Corporation shows a breakdown of this category between private grants $(\$ 20,747,857)$ and sources other than private grants $(\$ 42,862,053) .{ }^{54}$ Information from local legal services centers provides some further detail about the sources of this set of funds. Often the funds come from state bar foundations that wish to support the provision of legal services to low-income citizens. ${ }^{55}$ Other

53 Officially the Legal Services Corporation calls this category "private and other." See http://www.lsc.gov/sfb99nlf.html (visited 9/21/99).

${ }_{55}$ See 1997 Annual Report, Legal Services Corporation, at 7.

55 See, for example, http://www.nolac.org/humanresources.html (visited 9/21/99) (New Orleans Legal Assistance Corporation) (reporting $\$ 160,250$ in funding from the Louisiana Bar Foundation and \$20,746 in funding from "other foundations"); http://www.gulfcoastlegal.org/ (visited 9/21/99) (Gulfcoast Legal Services) (listing funding sources including the Florida Bar Foundation); 
foundations, as well as private individuals, may contribute as well, although in these instances the fraction of support provided by such actors, as compared to government sources, is far smaller than in the case of national issue organizations. ${ }^{56}$ United Way campaigns are also another frequent source of funding. ${ }^{57}$

It should be noted in conclusion that entities that receive funds from the Legal Services Corporation are currently prohibited from collecting attorneys' fees from opposing parties (Udell 1998a:338). Thus, while some employment laws provide for the recovery of attorneys' fees from employers under certain circumstances (as described more fully in section 1 above), entities that receive funds from the Legal Services Corporation are not presently eligible for this source of private funding. By contrast, as noted above, recovery of attorneys' fees can be a meaningful source of funding for national issue organizations. ${ }^{58}$ The Supreme Court recently struck down a different aspect of Congress's limitations on the activities of entities that receive corporation funds (see Legal Services Corporations v. Velazquez, 121 S. Ct. 1043 (2001)), but the case did not involve the restriction on recovery of attorney's fees or any of the other restrictions discussed in this chapter.

http://www.greenwood.net/ lsawc/about_us.htm (visited 9/22/99) (Legal Services Agency of Western Carolina) (listing funding sources including the South Carolina Bar Foundation).

56 See, for example, http://www.nwls.org/funding.htm (visited 9/21/99) (Northwestern Legal Services) (listing, as its sole source of private monetary support, a single foundation, but going on to note that this foundation donated \$300); http://www.ptla.org/funding.htm (visited 9/22/99) (Pine Tree Legal Assistance) (listing the Gene R. Cohen Charitable Foundation, the Stephen and Tabitha King Foundation, and individual donors as contributors, but noting that $85 \%$ of funding comes from governmental sources and IOLTA).

57 See, for example, http://www.lsnj.org/glance.html (visited 9/22/99) (Legal Services of New Jersey) (listing funds received from United Way campaigns); http://www.nwls.org/funding.htm (visited 9/21/99) (Northwestern Legal Services) (similar); http://www.svlas.org/ (visited 9/21/99) (Southwest Virginia Legal Aid Society) (similar).

58 See, for example, 1998 Annual Report, NAACP Legal Defense and Education Fund, at 24 (reporting $\$ 1,116,878$ in recovered fees and costs). 


\section{The relationship between funding sources and the nature of legal work performed by national issue organizations and legal services centers}

The previous two sections described national issue organizations and legal services centers and their respective sources of funding. This section looks more closely at the relationship between funding sources and the nature of employment law representation provided by each type of entity.

The basic thesis advanced here is that the different funding sources of national issue organizations and legal services centers produce systematic differences in the nature of the employment law work they perform. In particular, national issue organizations, which depend for support largely on private donations from individuals and foundations, tend to focus on highprofile, publicly-charged issues such as discrimination and tend to work on a few important or influential cases rather than a large number of more day-to-day claims; legal services centers, which depend for support largely on government sources, focus heavily on less controversial topics such as unemployment benefits and tend to work on many routine cases rather than a few attention-getting ones. The distinction is not hard and fast (and some counterexamples are discussed below, including the legal services "support centers" that used to play an important role), but it does capture a general difference between the two types of entities. Moreover, the distinction is an unsurprising consequence of the sorts of incentives created by the distinctive patterns of funding for the two types of entities.

As a result of the link between funding sources and activities, neither national issue organizations nor legal services centers succeed very well in meeting the full set of employees' needs for legal representation. The objective function of these organizations is tilted 
(understandably) toward maintaining the funding they need, and the natural result of this dependence is distortion in the activities that they perform.

\section{a. The relationship between funding and the subject matter of legal work \\ i. $\quad$ Subject matter of work by national issue organizations and legal services centers}

Even the brief descriptions in section 2 above suggest important differences in the subject matter of the employment law work on which national issue organizations and legal services centers focus. National issue organizations are disproportionately devoted to issues involving discrimination; fourteen of the nineteen organizations listed in Table 1 are exclusively or virtually exclusively devoted to discrimination issues (as their titles suggest), and an additional two organizations, the Lawyers' Committee for Civil Rights Under Law and the National Partnership for Women and Families, give heavy emphasis to such issues. Furthermore, the American Civil Liberties Union devotes a substantial amount of attention to discrimination issues; it also focuses heavily on other similarly high-profile civil liberties issues. The only national issue organizations that do not devote most of their energies to discrimination or other high-profile civil liberties issues are the Guild Law Center for Economic and Social Justice, which focuses on plant closings, and the National Employment Law Project, which works on a range of employment law topics including unemployment, benefits, wrongful discharge and

discrimination. ${ }^{59}$ It also bears noting that the Guild Law Center, while national, is tiny, with only

59 See notes 18 and 24 above (describing the Guild Law Center and the National Employment Law Project). Other national entities that, like these two, focus on the plight of low-income individuals, and that thus might be more likely to be concerned with more mundane legal topics than the rest of the national issue organizations, include the National Center on Poverty Law and the Center for Law and Social Policy, but neither of these entities at present appears active in the employment law area, although the Center for Law and Social Policy apparently was in the past. See http://www.povertylaw.org/ (visited 7/7/00) (National Center on Poverty Law home page, 
three lawyers on its staff. ${ }^{60}$ The National Employment Law Project, however, is a key national player that has litigated major cases and submitted Supreme Court amicus briefs on employment law issues that have lower public profiles than discrimination claims; the Project is thus the major exception to the general pattern described in this chapter. ${ }^{61}$

By contrast, legal services centers focus heavily within the employment area on unemployment benefits claims, as noted in section 2 above. Indeed, help in getting clients unemployment benefits that have been denied to them is a service that is routinely provided by most legal services centers. ${ }^{62}$ In contrast, wage claims and discrimination claims, while handled by some centers, are very far from universal in their coverage. For wage claims, the centers most likely to handle them seem to be those that focus on serving migrant workers and seasonal farmworkers. ${ }^{63}$ Discrimination claims are handled by such centers as Gulfcoast Legal Services, Inc. (which, in a fairly unusual practice, explicitly lists discrimination as one of its "priorities"), Atlanta Legal Aid, Client Centered Legal Services of Southwest Virginia, Legal Services of

containing link to Case Reports section, which does not reveal any employment law work); http://www.clasp.org/faq2.htm (visited 7/10/00) (describing subject areas in which the Center for Law and Social Policy works); Settle and Weisbrod (1978:288 n.23) (describing occupational safety and health litigation in the 1970s by the Center for Law and Social Policy).

60 See http://www.sugarlaw.org/about/staff.htm (visited 7/17/00).

61 Recent cases involving the National Employment Law Project include Ansoumana v. Gristede's Operating Corp., 201 F.R.D. 81 (S.D.N.Y. 2001), a large-scale class action brought under the Fair Labor Standards Act, and Auer v. Robbins, a Supreme Court case involving the Fair Labor Standards Act in which the Project submitted an amicus brief, see Brief of National Employment Law Project, Inc. as Amicus Curiae in Support of Petitioners, Auer v. Robbins, No. 95-897, United States Supreme Court, 1996 WL 492324.

${ }_{62}$ See, for example, http://www.greenwood.ned/ lsawc/case_acceptance.htm (visited 9/22/99) (Legal Services Agency of Western Carolina) (unemployment benefits claims are "routinely accepted for representation"); http://philalegal.org/info.htm (visited 9/22/99) (Philadelphia Legal Assistance) (listing unemployment benefits claims as a service area).

63 See, for example, http://www.mnlegalservices.org/about/mls.shtml (visited 7/11/00) (listing wage matters handled by Migrant Legal Services, a unit of Southern Minnesota Regional Legal Services); http://www.mlan.net/fwls/flsenglish.htm (visited 7/11/00) (similar for Farmworker Legal Services, a division of Legal Services of Southeastern Michigan). 
Northern Virginia, and the Knoxville Legal Aid Society. ${ }^{64}$ Other centers, by contrast, seem to focus exclusively or almost exclusively on unemployment benefit claims in their work in the employment area. At Legal Services of Eastern Missouri, for example, "[e]mployment cases usually involve the loss or denial of unemployment benefits." ${ }^{, 65}$ And at the Legal Services Agency of Western Carolina, while unemployment benefits claims are "routinely accepted for representation," other "employment problems" are "routinely rejected for representation." Some centers explicitly provide that discrimination claims are not handled. ${ }^{67}$

Sometimes only new resources allow a center to branch out and handle additional types of employment law claims. For instance, the New Orleans Legal Assistance Corporation reports in its 1998 Annual Report of handling wage and discrimination claims for the first time in twenty years due to the assistance of a Skadden Fellow (a recent elite law school graduate whose salary is paid by the law firm of Skadden, Arps, Slate, Meagher \& Flom). ${ }^{68}$

Thus, legal services centers focus on unemployment benefits claims and typically handle areas such as discrimination only sporadically, if at all. In this connection, it is interesting to note that, as mentioned briefly above, the National Employment Law Project, the only national issue organization to devote attention to the unemployment area, also used to be funded by the Legal

64 See http://www.gulfcoaselegal.org/priorites.htm (visited 9/21/99) (Gulfcoast Legal Services); http://www.law.emory.edu/PI/ALAS/97cases.html (visited 9/21/99) (Atlanta Legal Aid); http://iceman.naxs.com/ccls.info.htm (visited 9/21/99) (Client Centered Services of Southwest Virginia); http://members.aol.com/lsnvmain/programs.htm (visited 9/21/99) (Legal Services of Northern Virginia); http://korrnet.org/klas/problems.htm (visited 9/21/99) (Knoxville Legal Aid Society).

${ }_{65}$ See http://www.lsem.org/services.htm (visited 9/21/99).

66 See http://www.greenwood.ned/ lsawc/case_acceptance.htm (visited 9/22/99).

67 Palmetto Legal Services of South Carolina is an example. See http://www.netside.com/ legalpal/priority.htm (visited 9/29/99).

${ }_{68}$ See http://www.nolac.org/humanresources.htm (visited 9/21/99). 
Services Corporation ${ }^{69}$ and in fact served as a national legal services "support center," authoring publications to assist local legal services centers on employment law matters (see, for instance, National Employment Law Project 1975). Legal services support centers are discussed more fully below.

\section{ii. $\quad$ The role of funding}

The subject matter differences between national issue organizations and legal service centers seem unsurprising in light of their different funding sources. If an entity wishes to raise significant amounts of money from foundations and particularly private individuals, the entity is likely to have far more success if the entity's issues are high-profile and publicly visible. As Karen Paget (1990:123) notes, appeals to private individuals in particular need to be "as sharply ideological and urgent as possible." Joni Hersch (2001:[draft at 12]) observes that "[t]he need to generate media coverage in some cases may lead organizations to sacrifice substantive achievements for more newsworthy events that will generate greater visibility." A plea for funds to help fight discrimination in the workplace seems likely to attract far more foundation, and particularly far more individual, support than a plea for funds to ensure the integrity of the unemployment benefits system.

At the same time, government funders may be more hesitant to fund relatively controversial types of legal claims than relatively mundane types, such as claims for unemployment benefits. An illustration here is the fact that, as noted above, the state of Washington has a law prohibiting the use of IOLTA funds (similar in certain respects to government funds) for bringing employment discrimination claims (Udell, 1998b:908 n.42).

69 See, for example, Legal Services Corporation Authorizes Temporary Program Funding, PR Newswire, Dec. 30, 1988 (available on Lexis). 
Alan Houseman, Director of the Center for Law and Social Policy, offers a similar argument in response to the idea that government funds for legal services should have flowed to entities like the NAACP Legal Defense and Education Fund rather than to the sorts of entities that received them; he says that had entities similar to the NAACP Legal Defense and Education Fund applied for funds, "they would have sought funds for national civil rights and constitutional rights litigation," and "[f]unding such entities for civil rights and constitutional litigation would have created a political fight" (Houseman 1995:1681).

A further point related to funding sources and the subject matter of legal work is that the congressional prohibition on recovery of attorneys' fees by any entity receiving any Legal Services Corporation funds, noted above, makes employment discrimination cases even less attractive for such entities.

In all, then, there are important subject matter differences between the work of national issue organizations and that of legal services centers, and these differences seem to mesh up with the differences in funding sources.

\section{b. The relationship between funding and the nature or type of legal work}

If the differences in subject matter were the only salient differences between national issue organizations and legal services centers, then there might be relatively little cause for interest or concern. For if national issue organizations raised money largely from private donors and then worked on high-profile issues, while legal services centers got funded largely by the government and then worked on more mundane issues, but both types of legal issues were fully covered, it might not matter that there were differences between national issue organizations and legal services centers. The difficulty, however, is that, as detailed in this subsection, the two 
types of legal issues are generally not being covered in the same way. Instead, the nature or type of work is quite different across national issue organizations and legal services centers, and again the difference traces directly to the difference in funding sources.

\section{i. $\quad$ Nature or type of work by national issue organizations and legal services centers}

By and large, national issue organizations and legal services centers pursue cases at very different levels of the judicial system and have very different goals in their legal representation. A brief introductory point is in order here: Although this section will often use the term "impact" to refer to the sort of representation in which national issue organizations engage, it does so without meaning to embrace in an uncritical fashion the oft-drawn distinction between "impact" or "law reform" work, on the one hand, and individual client representation, on the other (Handler 1978a:26-27). Marc Feldman (1995:1537-38) nicely recaps the distinction:

Service cases, undertaken for individual clients, ... respond to the immediate problems of specific clients who present themselves at a program's offices seeking assistance. ... Impact cases, on the other hand, are viewed as significant and special. These rare cases seek to advance the interests of a number of . . . persons by 'reforming' some widespread practice or abuse.

However, the distinction between impact work and client service work is problematic on a number of grounds, perhaps particularly when used normatively to suggest the superiority of impact work (Trubek 1995:1133-34; White 1987-88:535-38). But for my descriptive purposes it is useful to distinguish in a rough way between work done to affect large numbers of individuals and work focused on meeting the individual needs of a particular client. Yet a third category is "implementation" work, or ensuring that legal victories in the courts are translated into real results "on the ground" (Sturm 1993a:727). But this category is probably less pressing in the 
employment area than in the area of prison and other institutional reform work-the area in which the implementation model is often discussed (see, for instance, Sturm 1993b:10, 15-16, 33-37).

National issue organizations typically focus their energies on a small number of impacttype cases, often at the appellate level of the judicial system. This emphasis is illustrated most starkly in the way in which these organizations explicitly discourage any impression that they are a resource for representing everyday claimants; for example, the web site for the Western Regional Office of the NAACP Legal Defense and Education Fund contains this stern statement:

The [office] handles civil rights impact litigation. It does not offer direct services or legal advice. ... . [It] takes cases that it feels will have a significant impact on a large community of people. Often these are class action cases. ...

Attorneys are not available to speak with people in person or on the phone to offer legal advice. [The office] is able to accept requests for assistance only in writing. [The office] is unable to handle most of the cases that people bring to its attention. ... It usually takes $30-45$ days to receive a response. ${ }^{70}$

Other national issue organizations, such as Equal Rights Advocates, do accept phone calls from individuals seeking legal advice, but even there the organization will provide legal representation (as distinguished from information or referral to another lawyer) only in "compelling, precedentsetting cases.",71

By contrast, the primary emphasis for legal services centers is on serving large numbers of clients. The lead-off message of the Legal Services Corporation's President, Douglas Eakeley, in the Corporation's 1997 Annual Report, for example, is that the Corporation's "269 programs served some 2 million clients in 1997, closing 1.5 million cases, an increase over 1996.", ${ }^{, 2}$ Eakeley goes on to praise the fact that "[m]any programs . . . increased their efficiency by adopting advanced telephone intake systems that facilitated access to their services over a

70 See http://www.ldfla.org/rfa.html (visited 9/3/99).

71 See http://www.equalrights.org/legal/index.htm (visited 7/10/00).

721997 Annual Report, Legal Services Corporation, at 2. 
large geographical area." ${ }^{, 73}$ As Gary Bellow (1980:340) wrote two decades ago, speaking of legal services, there is "an almost exclusive focus, publicly and administratively, on 'access' and how it is to be realized"; "graphs and tables" supplant "examples of practices changed and wrongs righted." While the NAACP Legal Defense and Education Fund brags in its annual report that it "has been involved in more cases before the U.S. Supreme Court than any organization except the U.S. Department of Justice, ${ }^{74}$ the claim to fame of the New Orleans Legal Assistance Corporation is that "[i]n 1998, [it] completed work on 6058 cases affecting 19,264 persons in total" with "completed cases averag[ing] about 300 per attorney." " In sharp contrast to the NAACP Legal Defense and Education Fund's emphasis on its role in the highest court in America, Danny Greenberg describes a legal services colleague who famously proclaimed that he (or she) had "the power to drag [an adversary] through the lowest courts in America. ${ }^{, 76}$ It is hard to imagine a more striking difference in emphasis between the two types of organizations.

The difference is not, of course, absolute. While it is clear that "there is relatively little impact work compared to service actually being done" by legal services centers (Bellow and Charn 1995:1645), it is also clear that at least a few centers do work on impact litigation. More likely than local centers to be involved with such litigation have been national or state-level "support centers" (previously called "backup centers"), which work together with local centers (Dooley and Houseman 1984:ch. I, p. 12; ch II, pp. 12-14; ch. III, p. 49). Although the role of these support centers has been greatly cut back in recent years (Houseman 1998:370), at least some of

\footnotetext{
73 Id.

741998 Annual Report, NAACP Legal Defense and Education Fund, at 2.

75 http://www.nolac.org/humanresources.htm (visited 9/21/99).

76 Proceedings of the Judicial Conference of the Second Judicial Circuit of the United States, 178 F.R.D. 210, 287 (1997) (statement of Daniel L. Greenberg).
} 
the centers appear to remain active, perhaps relying on alternative funding sources. (The support centers were previously funded at least in part by Legal Services Corporation funds (Spar 1996:2).) For instance, the Ohio State Legal Services Association State Support Center provides assistance, including direct representation of clients or co-counsel representation (presumably with the local center), to the eighteen local centers in Ohio and lists as one of its areas of coverage employment law, and in particular unemployment benefits. ${ }^{77}$ It may be that this sort of entity is more inclined than the local centers to take on unemployment benefits cases at higher levels of the judicial system.

Also in Ohio is ABLE, whose self-professed focus is "impact work.", 78 True to this characterization, ABLE has brought a number of fairly high-profile discrimination suits in the employment area, including suits against government actors. ${ }^{79}$ These are cases similar to those brought by national issue organizations. But does ABLE bring impact suits in more mundane areas such as unemployment benefits? Not in the particular area of unemployment benefits; the cases it mentions in that area are highly fact-specific and narrow, in stark contrast to the discrimination cases noted just above. ${ }^{80}$ But ABLE does mention a Fair Labor Standards Act case involving overtime that "could have an impact on the rest of the [landscape services]

77 See http://www.iwaynet.net/ oslsa/page2.html (visited 9/21/99).

78 See http://home.earthlink.net/ hn80/about.html (visited 9/22/99).

79 See http://home.earthlink.net/ hn80/report.html (visited 9/22/99) (describing ABLE cases such as Brown v. Winkle, a discrimination suit brought against the Toledo fire department that yielded a consent decree providing relief to minority employees, and Gonzales v. Felker, a discrimination suit brought against the Toledo police department that yielded a consent decree providing relief to minority employees).

80 See http://home.earthlink.net/ hn80/report.html (visited 9/22/99). (describing unemployment benefits cases involving issues such as the claim that being fired for a single offense violates company disciplinary procedure and the claim that a particular employer's work policy was too vague). 
industry in eastern Ohio." ${ }^{81}$ It also mentions a class action under the Fair Labor Standards Act, but this case had to be transferred to a non-legal-services attorney after the imposition of congressional restrictions that prohibited centers receiving Legal Services Corporation funds from representing parties in class actions. ${ }^{82}$ Thus ABLE appears to do some work (probably less in recent years as the congressional restrictions have grown) of an impact nature in areas of employment law not emphasized by national issue organizations, such as the Fair Labor Standards Act; like the National Employment Law Project, discussed above, it is an exception to the general pattern of behavior and funding of public-interest legal organizations.

A number of other legal services centers have traditionally (although perhaps less so in recent years assuming they continue to receive Legal Services Corporation funds) engaged in some impact work, including in the employment law area. For instance, Community Legal Services of Philadelphia litigated a major employment discrimination case in the 1970s (Carr and Hirschel 1998:320 n.3).

Nonetheless, it seems clear that impact work is not a staple of most legal services entities. This is particularly true for the local centers (as distinguished from the support centers, which, again, have been cut back in recent years). As Gary Bellow and Jeanne Charn (1995:1647) wrote fairly recently, "Many programs have abandoned any systematically oriented activities, treating the collective problems that plague the populations they serve as beyond their responsibility and competence." Feldman $(1995: 1535,1539)$ is similar. "Service work," he

81 See http://home.earthlink.net/ hn80/report.html (visited 9/22/99) (discussing Llamas v. Mentor Landscape \& Supply Co.).

82 See http://home.earthlink.net/ hn80/report.html (visited 9/22/99). (discussing Villareal v. Wiers Farms); Udell (1998a:338) (noting prohibition on representing parties in class actions). A related phenomenon is the spinning off of part of a legal services center into a new entity to handle the cases barred by the congressional restrictions; this is discussed further at the end of section 4 . 
says, rather than impact or law reform work, "constitutes the bulk of" legal services centers' effort. He continues: "Currently, a [legal services] program spends the vast majority of its legal resources on cases in which the horizon of ambition is defined, even at its maximum, by the individual client. The goal of the legal work is ... service to individual clients." Moreover, the congressional restrictions on Legal Services Corporation funds increase the degree to which this focus on individual client service exists, since, by banning class actions by entities that receive any financial support from the Legal Services Corporation (Udell 1998a:338), they cut off a significant avenue through which impact work may get done.

One response to the foregoing discussion is that perhaps there is relatively little largescale, impact-type work to be done in less high-profile areas of employment law such as unemployment benefits; thus, the argument would run, we see little of such work because there is simply little potential for it. (By contrast, it is clear that there is a large amount of service work for individual clients in high-profile areas such as discrimination.) The point about largescale work in less high-profile areas of employment law seems hard to address in a definitive way, but the conjecture nonetheless seems wrong. Procedures relating to employment benefits, for instance, can be and occasionally have been challenged on due process grounds in major class actions (see, for example, White v. Evans, 324 Md. 321 (1991)); it is not at all clear whyapart from the lack of adequate sources of legal representation-these actions should not be more common. Similarly, reemployment participation requirements for unemployment benefits (Emsellem and Halas 1995-96:298) may raise general legal issues that could benefit from impact-type litigation. Thus, there seem to be plausible areas of impact work that are not being well covered by existing public-interest legal organizations. 


\section{ii. $\quad$ The role of funding}

Once again, funding sources provide a clear explanation for the difference in the activities of national issue organizations and legal services centers. For national issue organizations, which, as noted, get most of their funds from private donations, it seems quite logical that raising money for high-impact work is easier than raising money to represent a large number of individuals in everyday, run-of-the-mill cases. Recall in this connection the NAACP Legal Defense and Education Fund's proud reference in its annual report to its dominant role in Supreme Court litigation. As Neil Komesar and Burton Weisbrod (1978:97) have suggested, "the incentives provided by funding decisions" push toward "sexy" or "test" cases rather than "efforts to enforce previous ... case determinations."

By contrast, the history of legal services centers makes painfully clear the quite different pressures that come with government funding. There is some dispute about how much impact work got done in the early days of legal services. Feldman (1995:1579-81) contends that impact work never figured importantly in the mission of legal services, while Fox (1998:305), Houseman (1995:1669, 1677-78, 1685-86), Johnson (1974:192-94), and Handler, Ginsberg and Snow (1978:45-46), all suggest that legal services in its founding years devoted meaningful focus to the impact model. However, what is clear is that at least a substantial fraction of centers, even early on in time, focused on representing a large number of individual clients rather than on bringing high-impact cases (Bellow 1980:338). This may have been in part because the centers adopted the existing model of "legal aid" societies, which had a similar focus (Feldman 1995:1562). ${ }^{83}$ Some authors also link the predominant focus on day-to-day, routine

83 Prior to the availability of federal government funding for legal services, the needs of lowincome clients were met by private legal aid societies supported by charitable contributions and 
representation to legal services' dependence on the support of the organized bar, which may have been threatened by a more aggressive embrace of impact work by legal services centers (Feldman 1995:1578), although other authors (Bellow and Charn 1995:1644) take a contrasting view.

But it seems clear that an important influence in the focus of legal services centers on individual client service was their dependence on government funding, for whenever these centers went beyond the client service model they seemed to encounter controversy. Johnson (1974:193) describes some early incidents in the history. By 1975 Congress had acted to restrict legal services centers from participating in school desegregation litigation (a classic form of impact litigation) (Parker 1994:1211 n.323). Similarly, welfare policy was one of the areas in which legal services lawyers were most active in doing impact work, but again this led quickly to controversy (Melnick 1994:75, 80-82). Houseman (1995:1687) succinctly summarizes some of the key episodes:

[T]he [legal services] program has been beset with the congressional and executive interference from the outset. It began in 1967 with the effort by Senator Murphy to ban suits against the government, and it continued throughout the history of the program: vetoes by governors over controversial programs; efforts to dismantle the program, first by Howard Phillips in 1973 and then again by President Reagan and his initial board of appointees in 1981-1984; and congressional restrictions on ... what kind of advocacy was permitted ...."

The legal services program found itself in "deep political trouble" shortly after its founding, and this trouble culminated in the removal of legal services from the "politics" of the Office of Economic Opportunity, the center of the War on Poverty, and its instatement in the separate Legal Services Corporation in the 1970s (Bellow 1980:340).

some municipal funding, as well as by individual lawyers on a voluntary basis (Bellow 1980:337). 
With the creation of the Corporation came, as Bellow (1980:340) has noted, "an almost exclusive focus, publicly and administratively, on 'access' and how it is to be realized." "The immediate goal now [was] . . 'minimum access'-defined as 2 lawyers per 10,000 poor people in the United States ...."

As Houseman describes, however, the 1970s reform did not ultimately quell controversy over the legal services program. Following the changes he notes, Congress in the mid-1990s ordered a major restructuring of the program. Substantial new restrictions were imposed on all entities receiving Legal Services Corporation Funds (Udell 1998a:337). Prompting these reforms was the sense "the program was founded for the purpose of handling the routine, day-to-day problems of poor people and that what had evolved was major impact litigation, which had politicized the entire program" (Forger 1998:335). As the Legal Services Corporation reported in its 1996 Annual Report:

Congress determined that federally funded programs should focus on individual cases, while efforts to address the broader problems of the client community should be left to entities that do not receive federal funds. Certain kinds of advocacy that have always been recognized as important tools for attorneys to employ on behalf of their clients, such as class actions and most legislative advocacy, would no longer be permitted for legal service attorneys, even if nonfederal funds were used for the purpose. ${ }^{84}$

The House Budget Committee was more direct: "Too often, ... lawyers funded through federal LSC grants have focused on political causes and class action lawsuits rather than helping poor Americans solve their legal problems" (Spar 1996:1).

The pressures against impact-type work imposed by government funding have not gone uncriticized. In Congress, Senator Kennedy decried the effect those pressures were having:

I personally do not think Washington should be deciding what legal issues local attorneys may raise on their client's behalf; I do not think Washington should be

84 See http://www.lsc.gov/anrep.html (visited 9/21/99). 
deciding what forums they can raise them in; and I most emphatically do not think we have any business telling a lawyer that the touchstone of whether or not to represent a client should be a measure of how controversial or how popular the issue. (Udell 1998b:901.)

But Senator Kennedy's lament did not ultimately carry the day, either in 1974, when it was first made, or in the subsequent controversies.

As a final note, it is interesting to observe the striking parallel between the argument here and Michael Selmi's (1998:1404, 1439) claim that direct government entities have a similarly narrow, circumscribed, cautious, bureaucratized focus in their work in the employment law area. Selmi studies the Equal Employment Opportunity Commission and the Department of Justice and concludes that these entities "concentrate [their] efforts on small, routine cases" with the primary goal of "process[ing] and dismiss[ing] claims" and the goal of remaining "politically uncontroversial" (pp. 1404, 1439, 1447-49). The similarities to the picture painted above of legal services work in the employment area are hard to overlook.

\section{c. Other organizations: Funding and nature of employment law work}

The discussion thus far has focused on two types of entities that provide legal representation in the employment law context: national issue organizations and legal services centers. The claim that has been advanced is that the work of these two types of entities produces a pattern of coverage of 1) impact claims for high-profile, publicly charged issues, and 2) day-to-day claims for mundane issues such as unemployment benefits. This pattern leaves uncovered the two remaining categories: impact claims in mundane areas and day-to-day claims in high-profile, publicly charged areas. These gaps in coverage are a natural consequence of the distortion of organizations' objective functions as a result of funding pressures. 
Do other public-interest legal organizations fill the void left by national issue organizations and legal services centers? That is the question examined briefly in this section. The analysis first looks at an important set of organizations that are similar to national issue organizations but appear to operate predominantly at the regional or local level. It next looks at the network of government-funded disability discrimination ("protection and advocacy") centers, which do case-by-case work in a variety of areas including employment discrimination, and thus represent an exception to the general dichotomy drawn in this chapter. For reasons of space, this discussion only scratches the surface; an important question for future work is what can be learned from the alternative models described here, particularly the model used in the disability discrimination context.

\section{i. "Regional issue organizations"}

Table 3 contains a list of organizations that are similar to national issue organizations but seem to operate primarily (although not necessarily exclusively) on a more regional or local level (although it is sometimes difficult to draw a sharp line between work on a rational level and work on a regional or local level). Like the entities listed in Table 1 above, the entities in Table 3 focus on a particular set of issues or topics related at least in part to employment law, and they appear to be funded largely or exclusively by sources other than the government. (Sometimes publicly available information did not disclose sources of funding, but in no case was there any indication of a significant role for government funding. For five organizations, the Asian Pacific American Legal Center of Southern California, Gay \& Lesbian Advocates \& Defenders, the Lawyers' Committee for Civil Rights Under Law (local affiliate centers), The Public Justice Center, and the Washington Lawyers' Committee for Civil Rights and Urban Affairs, there was 
neither an indication of government funding nor any reason to suspect government funding. For the Employment Law Center of the Legal Aid Society of San Francisco, there was no indication of government funding, but the organization might receive such funding because it is part of a legal aid organization. At the same time, the Center clearly receives substantial foundation funding. ${ }^{85}$ Other entities listed in the table provided more information about their funding, as detailed in the footnotes accompanying these entities.)

Table 3: "Regional issue organizations" (devoted at least in part to employment law issues)

\begin{tabular}{|l|}
\hline American Civil Liberties Union-state affiliates \\
Asian Pacific American Legal Center of Southern California \\
Center for Law in the Public Interest (Southern California) $^{88}$ \\
Employment Law Center of the Legal Aid Society of San Francisco $^{89}$ \\
Gay \& Lesbian Advocates \& Defenders (New England) $^{90}$ \\
Lawyers' Committee for Civil Rights Under Law-local affiliates $^{91}$ \\
Northwest Women's Law Center (Seattle) $^{92}$ \\
Public Advocates (western states) \\
The Public Justice Center (Maryland) $^{94}$ \\
Washington Lawyers' Committee for Civil Rights and Urban Affairs $^{95}$ \\
\hline
\end{tabular}

85 See Foundation Center, Grants List 1/98-4/98 (reporting \$107,000 grant from the Rosenberg Foundation to the Employment Law Center in 1998) (available in FGI database on Westlaw).

86 See, for example, http://www.aclu-mass.org/docket/docket99.2000.html (visited 7/5/01) (listing employment law cases including Monahan v. Dept. of State Police, Narrett v. Framingham State College, and Pereira v. Carlisle); http://www.aclumass.org/issuebriefs/guardianACLU.html (visited 7/5/01) ("The ACLU does not receive any government funding."). For links to all of the ACLU state affiliates, see http://www.aclu.org/community/community.html (visited 7/5/01).

${ }_{87}$ See http://www.safenetwork.net/rd/sn000348.htm (visited 7/10/00) (listing employment as one of several areas of activity).

88 See http://www.afj.org/mem/clpi.html (visited 7/12/00) (listing employment discrimination as one of several areas of activity); Barker (1997:56) (describing funding sources for the Center as being various grants, including from the Ford Foundation).

${ }^{89}$ See, for example, Slind-Flor (1998) (describing a case brought by the Employment Law Center that produced a ground-breaking ruling recognizing the right of employees to genetic and medical privacy).

90 See http://www.glad.org/home.html (visited 9/19/01) (general description of organization); http://www.glad.org/docket.html (visited 9/19/01) (discussing employment law litigation activities). 
In addition to the entities listed in Table 3, "legal services spin-offs"-entities spun-off from legal services centers in the wake of the congressional restrictions on Legal Services Corporation funds and the resulting difficulty of impact work for such centers-may look similar to "regional issue organizations." Carr and Hirschel (1998) offer a detailed case study of one such spun-off entity. Some spun-off entities may well be doing impact work in the employment area, but it is interesting to note that Community Legal Services of Philadelphia, which did impact work in the employment area when it was funded by the Legal Services Corporation, is now, since being spun off, focusing its attention away from litigation as a model (Carr and Hirschel 1998: 330-31).

Like the national issue organizations listed in Table 1, the organizations listed in Table 3 generally focus on issues involving discrimination and other high-profile civil liberties matters, as is apparent from the descriptions given in the footnotes just above. The closest thing to an exception to this pattern is The Public Justice Center, which seems to do substantial work in the

91 See http://www.lawyerscomm.org/ (visited 9/3/01) (“local committees" link) (describing functions of local affiliates and listing employment discrimination as one area of practice).

92 See http://www.nwwlc.org/issues_employmentdiscrimination.shtml (visited 7/10/00) ("Employment Discrimination: Impact Litigation" description for the Northwest Women's Law Center); http://www.nwwlc.org/main/content/lawcenter/annualreport.shtml (visited 10/15/01) (listing sources of funding as special events, individual contributions, grants, seminars, and other).

93 See Center for Public Interest Law (1995:19) (describing employment as an area of concentration for Public Advocates); Arriola and Wolinsky (1983:1219-21) (describing employment class action brought by Public Advocates); Fried (1998:9) (referring to Public Advocates as an "independent nonprofit," in explicit contrast to the Legal Aid Society of Alameda County, a legal services center); Barker (1997:56) (referencing Ford Foundation funding for Public Advocates).

94 See http://www.publicjustice.org/reports.html (visited 7/11/00) (link to "Cases and Projects List," which summarizes employment law cases such as Talavera v. Hill \& Sanders Ford (a discrimination suit) and Heath v. Perdue Farms, Fox v. Tyson Foods, Inc., and Trotter v. Perdue Farms, Inc. (all suits involving wage and hour issues, presumably under the Fair Labor Standards Act)).

95 See http://www.washlaw.org/default.htm (visited 7/3/01) (listing employment law as one of several areas of activity). 
wage and hour area, as the description given above shows. But even that organization (like the National Employment Law Project, the primary outlier among the national issue organizations in Table 1), also works on employment discrimination issues.

Also like the organizations in Table 1, the organizations in Table 3 are involved acrossthe-board in impact litigation. For instance, the Asian Pacific American Legal Center of Southern California has "spearheaded several lawsuits which have had a strong impact in the legal community," and the Northwest Women's Law Center "brings public impact cases throughout the Northwest." ${ }^{96}$ Some of these organizations may also do some individual representation; for instance, The Public Justice Center seems to engage in some such activity. ${ }^{97}$ But other organizations on Table 3 appear to be limited to impact work in their representation activities. $^{98}$

\section{ii. Day-to-day representation in discrimination cases: The case of disability}

The "regional issue organizations" just discussed fit neatly into the dichotomy drawn in this chapter between national issue organizations and legal services centers, since the regional

96 See http://www.safenetwork.net/rd/sn000348.htm (visited 7/10/00) (Asian Pacific American Legal Center of Southern California); http://www.nwwlc.org/main/content/lawcenter/ (visited 7/17/00) (Northwest Women's Law Center); see also Barker (1997:56) (describing an employment discrimination suit brought by the Center for Law in the Public Interest against the Los Angeles fire department forcing the department to hire more black and Hispanic employees); Center for Public Interest Law (1995:19) (describing class action activity of Public Advocates); http://www.publicjustice.org/reports.html (visited 7/11/00) (link to "Cases and Projects List," which summarizes Trotter v. Perdue Farms, Inc., a nationwide class action wage and hour lawsuit).

97 See http://www.publicjustice.org/reports.html (visited 7/11/00) (link to "Cases and Projects List," which summarizes Talavera v. Hill \& Sanders Ford, which appears to be a fairly factspecific discrimination case).

98 See, for example, http://www.nwwlc.org/main/content/lawcenter (visited 7/17/00) (Northwest Women's Law Center) (describing services as a combination of "impact litigation" and "self help" for individuals through information packets and a telephone hotline (but not legal representation)). 
organizations are so similar to the national issue organizations. Less easy to fit comfortably within the dichotomy are the state centers across the country serving the needs of disabled individuals, including disabled employees. ${ }^{99}$ These centers are funded by the government (at least to a significant degree) and focus at least in significant part on day-to-day representation of individual clients ${ }^{100}$-so in those respects they are like legal services centers-but their primary focus in the employment area is, not surprisingly, discrimination ${ }^{101}$-so in that respect they are like national (and regional) issue organizations.

The example of disability centers, while important and interesting, does not disrupt in a fundamental way the more general idea that for many types of discrimination claims, legal representation on day-to-day matters seems likely to be severely limited. Lynn Kelly (1998:725) notes that "there is almost no representation of low wage workers with discrimination claims." At the same time, the disability example similarly does not alter the suggestion above that legal representation for impact work in relatively mundane areas of employment law such as unemployment benefits is highly inadequate and incomplete.

\section{Conclusion}

It bears emphasis that this chapter has not attempted to provide anything approaching a comprehensive normative assessment of how a range of legal institutions should, in an ideal

99 See 2000 Annual Report, National Association for Protection and Advocacy Systems, at 1-3 (overviewing activities of state centers).

${ }_{100}$ See http://www.protectionandadvocacy.com/brochur1.htm (visited 7/14/00) (describing various government programs including PADD, PAIMI, and PAIR); 2000 Annual Report, National Association for Protection and Advocacy Systems, at 5 (listing large number of clients represented by state centers).

${ }^{101}$ See, for example, http://www.pai ca.org/pubs/500801.html (visited 7/14/00) (Protection \& Advocacy, Inc., of California) (listing employment discrimination as a service area, and not listing any other employment problems); http://www.dlc-ma.org/programs.html (visited 9/2/99) (Disability Law Center of Massachusetts) (similar). 
world, function to enforce the employment laws. Projects of that broader and necessarily rather speculative sort have been undertaken in other contexts; for instance, Susan Sturm (1993b) has offered a broad set of recommendations for improving the enforcement of laws in another context involving even more vulnerable beneficiaries-the prisoners' rights context-and Houseman (1995) has recently undertaken a similar project for legal advocacy for low-income individuals in general. Joel Handler (1978b:283-84) offers some brief remarks on the question of optimal institutional design in the specific context of employment discrimination law (although not employment law generally), prescribing a broad division of roles among government, private, and public interest actors. The emphasis of the present inquiry, by contrast, has been on highlighting two central types of public-interest legal organizations involved in the enforcement of the employment laws and on assessing some of their features and functions.

This work also has not attempted to model in a comprehensive way the objective function of public-interest legal organizations working in the employment law area. Previous work on public-interest legal organizations in general (not specifically in the employment law area) has catalogued various of the objectives they may pursue (Komesar and Weisbrod 1978:81-89, 9699). The discussion here has focused more specifically on a particular and apparently distorting feature of the objective function of public-interest legal organizations working in the employment law area-the emphasis on attracting and maintaining funding from either large private donors, such as foundations, or the government. My conclusion about the apparently distorting nature of funding of public-interest legal organizations in the employment law area meshes with the more general conclusion reached by Neil Komesar and Burton Weisbrod (1978:96-97) about funding-based distortions in public-interest legal organizations in a range of areas. 
Future work might look at types of legal institutions other than those considered here-for instance, pro bono models, law school clinical programs, social justice law firms, and client nonprofits. As Louise Trubek (1998:805) notes, some large law firms have set up community law offices as part of their pro bono efforts, and Lawrence Fox (1998:315) describes the Litigation Assistance Partnership Project, an American Bar Association initiative that matches legal services centers needing help on major cases with private law firms seeking pro bono work. A broader inquiry into these additional types of institutions, and their potential role in enforcing the employment laws, would also have to face the fundamental question of whether more aggressive litigation of employment law claims would in the end help employees-a question whose answer depends on the degree to which the courts are likely to rule in favor rather than against employees' claims. 


\section{References $^{102}$}

Arriola, Anita P. and Sidney M. Wolinsky. 1983. Public Interest Practice In Practice: The Law and Reality. Hastings Law Journal 34:1207-1229.

Barker, Emily. 1997. Doing Good, Doing Well. American Lawyer (June):53-60.

Bellow, Gary. 1980. Legal Aid in the United States. Clearinghouse Review 14:337-345.

Bellow, Gary and Jeanne Charn. 1995. Paths Not Yet Taken: Some Comments on Feldman's Critique of Legal Services Practice. Georgetown Law Journal 83:1633-1668.

Burstein, Paul. 1991. Legal Mobilization as a Social Movement Tactic: The Struggle for Equal Employment Opportunity. American Journal of Sociology 96:1201-1225.

Carr, Catherine C. and Alison E. Hirschel. 1998. The Transformation of Community Legal Services, Inc., of Philadelphia: One Program's Experience Since the Federal Restrictions. Yale Law and Policy Review 17:319-335.

Center for Public Interest Law. 1995. Public Interest Organizations. California Regulatory Law Reporter 15(1):16-20.

Dooley, John A. and Alan W. Houseman. 1984. Legal Services History.

Emsellem, Maurice and Monica Halas. 1995-96. Representation of Claimants at Unemployment Compensation Proceedings: Identifying Models and Proposed Solutions. University of Michigan Journal of Law Reform 29:289-332.

Feldman, Marc. 1995. Political Lessons: Legal Services for the Poor. Georgetown Law Journal 83:1529-1632.

Fisk, Catherine. 2001. Union Lawyers and Employment Law, abstract available at http://papers.ssrn.com/sol3/papers.cfm?abstract_id=271150.

Forger, Alexander D. 1998. The Future of Legal Services. Fordham Urban Law Journal 25:333-343.

Fox, Lawrence J. 1998. Legal Services and the Organized Bar: A Reminiscence and a Renewed Call for Cooperation. Yale Law and Policy Review 17:305-317.

Fried, Rinat. 1998. The LSC Investigates Its Offspring. The Recorder (April 2):9.

102 This section lists books, book chapters, academic articles on the internet, and articles in regularly published periodicals referenced in the chapter. For court decisions, publications by public-interest legal organizations, and internet sources apart from sources for academic articles, complete bibliographic information appears in the endnotes. 
Gordon, Jennifer. 1995. We Make the Road by Walking: Immigrant Workers, the Workplace Project, and the Struggle for Social Change. Harvard Civil Rights-Civil Liberties Law Review 30:407-450.

Handler, Joel F. 1978a. Social Movements and the Legal System: A Theory of Law Reform and Social Change. New York, NY: Harcourt Brace Jovanovich.

Handler, Joel F. 1978b. Public Interest Law and Employment Discrimination. In Public Interest Law: An Economic and Institutional Analysis, ed. Burton A. Weisbrod. Berkeley, CA: University of California.

Handler, Joel F., Betsy Ginsberg and Arthur Snow. 1978. The Public Interest Law Industry. In Public Interest Law: An Economic and Institutional Analysis, ed. Burton A. Weisbrod. Berkeley, CA: University of California.

Hersch, Joni. 2001. Time for an Employees' Lobby? (working paper).

Houseman, Alan W. 1998. Civil Legal Assistance for the Twenty-first Century: Achieving Equal Justice for All. Yale Law and Policy Review 17:369-433.

Houseman, Alan W. 1995. Political Lessons: Legal Services for the Poor-A Commentary. Georgetown Law Journal 83:1669-1709.

Issacharoff, Samuel. 1996. Contracting for Employment: The Limited Return of the Common Law. Texas Law Review 74:1783-1812.

Johnson, Denise R. 1998. The Legal Needs of the Poor as a Starting Point for Systematic Reform. Yale Law and Policy Review 17:479-488.

Johnson, Earl Jr. 1974. Justice and Reform: The Formative Years of the OEO Legal Services Program. New York, NY: Russell Sage.

Kelly, Lynn M. 1998. Lawyering for Poor Communities on the Cusp of the Next Century. Fordham Urban Law Journal 25:721-728.

Komesar, Neil K. and Burton A. Weisbrod. 1978. The Public Interest Law Firm: A Behavioral Analysis. In Public Interest Law: An Economic and Institutional Analysis, ed. Burton A. Weisbrod. Berkeley, CA: University of California.

Llewellyn, Karl N. 1930. A Realistic Jurisprudence-The Next Step. Columbia Law Review 30:431-465.

Lopez, Felix. 1998. Lawyers Matter, Policy Matters: How One Small Not-for-Profit Combats Discrimination Against Ex-Offenders, People in Recovery, and People with AIDS. Yale Law and Policy Review 17:443-454. 
Maltby, Lewis L. 1998. Private Justice: Employment Arbitration and Civil Rights. Columbia Human Rights Law Review 30:29-64.

Melnick, R. Shep. 1994. Between the Lines: Interpreting Welfare Rights. Washington, DC: Brookings.

National Employment Law Project. 1975. Legal Services Manual for Title VII Litigation.

O’Connor, Karen and Lee Epstein. 1989. Public Interest Law Groups: Institutional Profiles. New York, NY: Greenwood.

Paget, Karen. 1990. Citizen Organizing: Many Movements, No Majority. The American Prospect (Summer):115-128.

Parker, Wendy. 1994. The Future of School Desegregation. Northwestern University Law Review 94:1157-1227.

Pound, Roscoe. 1910. Law in Books and Law in Action. American Law Review 44:12-36.

Resnick, Judith and Emily Bazelon. 1998. Legal Services: Then and Now. Yale Law and Policy Review 17:291-303.

Rutherglen, George. 1995. From Race to Age: The Expanding Scope of Employment Discrimination Law. Journal of Legal Studies 24:491-521.

Selmi, Michael. 1998. Public vs. Private Enforcement of Civil Rights: The Case of Housing and Employment. UCLA Law Review 45:1401-1459.

Settle, Russell F. and Burton A. Weisbrod. 1978. Occupational Safety and Health and the Public Interest. In Public Interest Law: An Economic and Institutional Analysis, ed. Burton A. Weisbrod. Berkeley, CA: University of California.

Slind-Flor, Victoria. 1998. Workers Have Right to Privacy. National Law Journal (February 16):A8.

Spar, Karen. 1996. Legal Services Corporation: Basic Facts and Current Status, Congressional Research Service Report for Congress, Oct. 23.

Sturm, Susan P. 1993a. The Legacy and Future of Corrections Litigation. University of Pennsylvania Law Review 142:639-738.

Sturm, Susan P. 1993b. Lawyers at the Prison Gates: Organizational Structure and Corrections Advocacy, University of Michigan Journal of Law Reform 27:1-129. 
Trubek, Louise G. 1998. Reinvigorating Poverty Law Practice: Sites, Skills and Collaborations. Fordham Urban Law Journal 25:801-811.

Trubek, Louise G. 1996. Embedded Practices: Lawyers, Clients, and Social Change. Harvard Civil Rights-Civil Liberties Law Review 31:415-441.

Trubek, Louise G. 1995. The Worst of Times ... and the Best of Times: Lawyering for Poor Clients Today. Fordham Urban Law Journal 22:1123-1140.

Udell, David S. 1998a. The Legal Services Restrictions: Lawyers in Florida, New York, Virginia, and Oregon Describe the Costs. Yale Law and Policy Review 17:337-368.

Udell, David S. 1998b. Implications of the Legal Services Struggle for Other Government Grants for Lawyering for the Poor. Fordham Urban Law Journal 25:895-922.

Weil, David. 2001. Individual Rights and Collective Agents: The Role of Old and New Workplace Institutions in the Regulation of Labor Markets (working paper).

Weisbrod, Burton A. 1978. Conceptual Perspective on the Public Interest: An Economic Analysis. In Public Interest Law: An Economic and Institutional Analysis, ed. Burton A. Weisbrod. Berkeley, CA: University of California.

White, Lucie E. 1987-88. Mobilization on the Margins of the Lawsuit: Making Space for Clients to Speak. New York University Review of Law and Social Change 16:535-564.

Willborn, Steven, Stewart Schwab and John F. Burton. 1998. Employment Law: Cases and Materials. Charlottesville, VA: Lexis. 